University of Windsor

Scholarship at UWindsor

$1-2019$

\title{
Unnatural Amino Acids Improve Affinity and Modulate Immunogenicity: Developing Peptides to Treat MHC Type II Autoimmune Disorders
}

\author{
Daniel Meister \\ Department of Chemistry and Biochemistry, University of Windsor \\ S. Maryamdokht Taimoory \\ Department of Chemistry and Biochemistry, University of Windsor \\ John F. Trant \\ Department of Chemistry and Biochemistry, University of Windsor
}

Follow this and additional works at: https://scholar.uwindsor.ca/chemistrybiochemistrypub

Part of the Biochemistry, Biophysics, and Structural Biology Commons, and the Chemistry Commons

\section{Recommended Citation}

Meister, Daniel; Taimoory, S. Maryamdokht; and Trant, John F.. (2019). Unnatural Amino Acids Improve Affinity and Modulate Immunogenicity: Developing Peptides to Treat MHC Type II Autoimmune Disorders. Peptide Science, 111 (1), e24058.

https://scholar.uwindsor.ca/chemistrybiochemistrypub/143

This Article is brought to you for free and open access by the Department of Chemistry and Biochemistry at Scholarship at UWindsor. It has been accepted for inclusion in Chemistry and Biochemistry Publications by an authorized administrator of Scholarship at UWindsor. For more information, please contact scholarship@uwindsor.ca. 


\section{Notice:}

This is the peer reviewed version of the following article by Meister et al., which has been published in final form at https://doi.org/10.1002/pep2.24058. This article may be used for noncommercial purposes in accordance with Wiley Terms and Conditions for Use of Self-Archived Versions.

Meister, D., Taimoory, S. M., \& Trant, J. F. (2019). Unnatural amino acids improve affinity and modulate immunogenicity: Developing peptides to treat MHC type II autoimmune disorders. Peptide Science, 111(1), e24058. 
Unnatural Amino Acids Improve Affinity and Modulate Immunogenicity: Developing Peptides to Treat MHC Type II Autoimmune Disorders

\author{
Daniel Meister, S. Maryamdokht Taimoory, John F. Trant* \\ Department of Chemistry and Biochemistry, University of Windsor, 401 Sunset Ave. Windsor, \\ Ontario N9B 3P4 Canada \\ j.trant@uwindsor.ca; Fax: 1-519-973-7098
}

Keywords: unnatural amino acids; altered peptide ligands; autoimmune disease; multiple sclerosis; celiac disease; rheumatoid arthritis

\begin{abstract}
:
Many autoimmune diseases, including multiple sclerosis (MS), rheumatoid arthritis (RA), and celiac disease (CD), arise from improper immune system recognition of self or benign peptides as threats. No autoimmune disease currently has a cure. Many treatments suppress the entire immune system to decrease symptom severity. The core molecular interaction underlying these diseases involves specific alleles of the human leukocyte antigen (HLA) receptor hosting the immunodominant peptides associated with the disease (i.e. myelin basic protein, Type II collagen, or $\alpha$-gliadin) in their binding groove. Once bound, circulating T-cells can recognize the HLAantigen complex and initiate the complex cascade that forms an adaptive immune response. This initial HLA-antigen interaction is a promising target for therapeutic intervention. Two general strategies have been pursued: altered peptide ligands (APLs) that attempt to recruit a different class of T-cell to induce an anti-inflammatory response to balance the pro-inflammatory response associated with the antigen; and HLA blockers (HLABs), peptides that, due to a much higher affinity for the HLA receptor, quantitatively displace the antigen, inhibiting the immune response. Both approaches would benefit from improved HLA-drug binding, but as the HLA receptors are highly promiscuous, the binding sites are not specific for any natural amino acid. Unnatural amino acids, either designed or screened through high-throughput assays, may provide a solution. This review summarizes the nascent field of using non-canonical residues to treat MS, RA and CD, focusing on the importance of specific molecular interactions, and provides some examples of the synthesis of these unnatural residues.
\end{abstract}

\title{
Introduction:
}

The increasing understanding of the critical role of peptides in human biology has led to a renewed focus on developing peptide therapeutics. Drug discovery and design has long been centered on small molecule synthesis. ${ }^{1}$ However, small molecules lack the precise specificity of peptides $^{2}$ and very often have off-target effects due to undesired secondary interactions. The comparatively large size and specificity of peptides offers a promising alternative. However, despite this potential, peptides have only seen very limited use as therapeutics partially due to cellular-uptake concerns, partially due to their low biostability, and partially due to their comparative synthetic complexity and/or expense. ${ }^{3}$ However, one of the greatest limiting factors 
is the co-evolution challenge. Therapeutic peptides are best suited for inhibiting, blocking, or agonizing targets that have endogenous peptide ligands with which they have co-evolved over approximately the past four billion years. Many of the natural targets have exceptional affinity, and so displacing them is a significant challenge. However, the systems have been developed exclusively using, with a few very notable exceptions, the canonical 20 amino acids. Using unnatural amino acids can possibly decouple this problem by introducing residues that can take advantage of latent interactions unavailable to any natural residue. With recent advances in in silico peptide design, and access to the significant computational resources required for this type of research $;{ }^{4}$ synthetic chemistry to develop new methods to access unnatural amino acids in efficient, rapid, and general ways; ${ }^{5}$ the understanding of peptide architectures, sequences, and modifications to improve proteolytic stability; ${ }^{6}$ and solid-phase peptide synthesis to allow for faster, cleaner, and massively parallel syntheses, ${ }^{7}$ we are potentially already in a renaissance for peptide-based drugs.

One of the most promising applications of the new peptide science is for developing new therapeutics for autoimmune disorders, especially the major histocompatibility complex (MHC) Type II disorders. ${ }^{8}$ These are all conditions where an individual carries a certain allele of the receptor that is capable of improperly identifying a self-peptide as foreign. This initiates an immune response whose symptoms differ based on the target protein or organ. Thus, the peptides that cause disease are not the natural ligands of the receptor. This makes them very promising targets for the therapeutic intervention with synthetic peptides that interfere with the immunogenic interaction. MHC Type II diseases include many of the most common immune diseases: multiple sclerosis (MS), celiac disease (CD), rheumatoid arthritis (RA) and type 1 diabetes (T1D) among many others. ${ }^{9}$ The presence of the allele significantly increases susceptibility to develop the disease but is not sufficient for disease onset. ${ }^{10}$ The overall mechanism in these types of disorders is very similar.

MHC class II molecules, also known as human leukocyte antigen (HLA) receptors, are present on the surfaces of epithelial cells. ${ }^{11}$ They are comprised of a heterodimer of two proteins: the $\alpha$ and $\beta$ chains. The peptide antigen binding groove emerges from the organization of two $\alpha$ helices forming walls, supported by an eight strand $\beta$-pleated sheet floor which open on both ends (Figure 1A). ${ }^{12}$ These receptors present antigenic peptides to CD4+ $\mathrm{T}$ cells initiating an immune response resulting in disease symptoms. The binding groove and antigenic peptide conformation is highly conserved between MHC type II molecules. The antigenic peptide is bound in an extended conformation within the groove and is held in position through non-covalent interactions between the peptide backbone and sidechains and the surface residues on the receptor. ${ }^{12}$ Generally, nine amino acids form the core binding region however the peptide may be longer as the binding pocket is open on both sides. In the bound conformation, several of the amino acid side-chains face towards the groove into distinct pockets. These residues form additional attractive interactions stabilizing the peptide-MHC complex and are termed anchor residues, found in positions p1, p4, p6 and p9 (Figure 1B). However, this pattern can vary based on the disease and associated peptide. For example, in some cases, it is $\mathrm{p} 7$ instead of $\mathrm{p} 6$ which is the anchor residue. The nature of the pockets (size, shape, hydrophobicity, electrostatic and electronics), as well as the preferred amino acid residue, varies depending on the exact sequence of the HLA receptor. These factors determine which peptides it is capable of recognizing, and defines which residues on the peptide epitope are involved in binding to the HLA. Several of the epitope's other amino acids in this core HLAbinding sequence of nine amino acids point away from the binding groove and participate in $\mathrm{T}$ cell recognition (Figure 1C). The T-cell uses its receptor then binds from the top face and forms a 
MHC-peptide-T cell ternary complex. This interaction then initiates the complicated adaptive immune response. Although incredibly highly polymorphic across the population, individuals have only between 8 and 12 different MHC receptors. However, there are approximately $10^{8}-10^{12}$ different circulating $\mathrm{T}$-cell receptors at any one time, and the best estimates indicate that the genetic code encodes on the order of $10^{20}$ possible different T-cell receptors. ${ }^{13}$ This difference in polymorphism is key to the interest that these materials have drawn from researchers using unnatural amino acids: the MHC receptors need to be capable of binding a very wide variety of different peptides; they are the primary recognition element for identifying pathogens for the immune system. However, because they must be promiscuous binders, they are not particularly strong binders of any given antigen; furthermore, as the pockets and potential interaction points along their surface must be capable of accepting a number of different amino acid guests, they are not specific for any given amino acid. As peptides are the natural ligand responsible for disease initiation, treatment with peptide drugs has been a focus of autoimmune research. There are two potential mechanisms that can be envisaged. The Altered Peptide Ligands (APLs) attempt to modulate the T-cell receptor face of the peptide in order to change the T-cell response from a proinflammatory mechanism to an anti-inflammatory mechanism. ${ }^{14}$ HLA-blockers (HLAB) on the other hand seek to improve binding to the $\mathrm{MHC}$, and thereby competitively displace the antigenic peptide and consequently prevent T-cell recognition of the complex altogether. ${ }^{15}$ APLs do not need to displace all the antigens to function: they need to occupy sufficient MHC receptors that their anti-inflammatory response balances the pro-inflammatory response elicited from the antigen. However, no traditional APL has reached the clinic (although there are a number of candidates, such as glatiramer triacetate ${ }^{16}$ that may have some APL activity in addition to other mechanisms). HLABs on the other hand rely on near complete displacement of the natural antigen. By removing the antigen, you remove the downstream immune response; but, for this to be viable, displacement must be near complete, and this implies an exceptional preference of the HLAB over the antigen for the HLA receptor. However, as the receptor is promiscuous by design, this is very difficult to do with natural amino acids. The current best efforts are on the order of a 55-fold improvement as observed by Sollid and co-workers in a CD model. ${ }^{17}$ But that does not mean that an unnatural amino acid cannot be designed that is specific for the pocket. These residues could, in theory, show far higher specific affinity, providing the required orders of magnitude increase in affinity that could lead to a new class of specific treatments for autoimmune diseases. To do this rationally, a detailed understanding and modelling of the various potential interactions that can be exploited to improve affinity is required. 


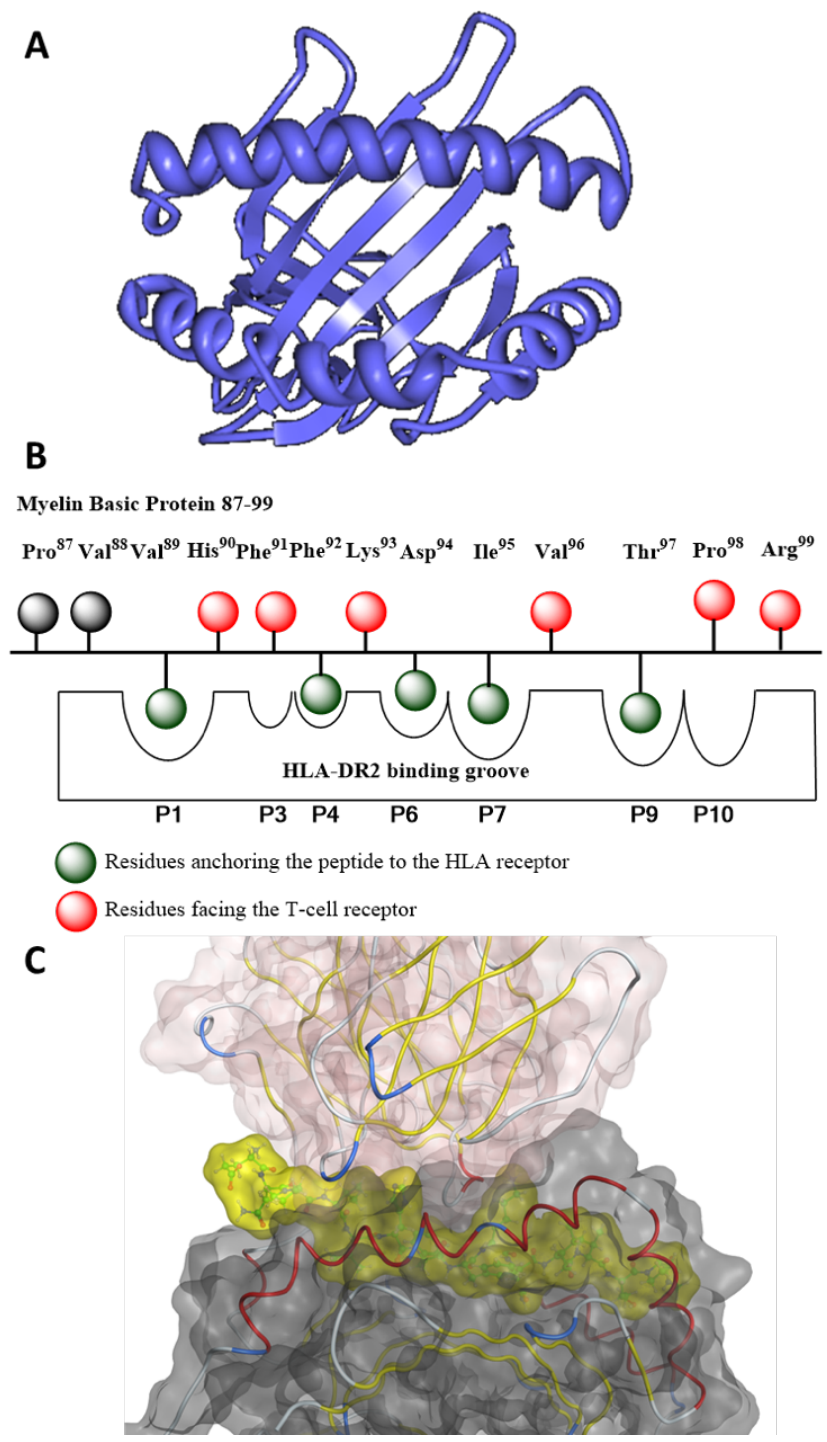

Figure 1. Overview of the MHC-peptide interaction. A) Top-down view of a crystal structure of an MHC-Type II receptor associated with RA ${ }^{18}$; B) Cartoon representation of myelin basic peptide 87-99, the immunodominant epitope strongly associated with the development of MS bound to HLA-DR2, an HLA receptor associated with many cases of MS. Key HLA contact residues are highlighted in green, key TCR-contact residues in red. The pockets on the HLA are indicated and their representation is broadly proportional to their respective size. C) Image of a T-cell receptor (top, yellow coil and pink surface) interacting with the HLA (bottom, grey surface)-antigen (middle yellow surface) complex obtained from an MS related crystal structure. ${ }^{19}$

Consideration of the nature and strength of each interaction between the amino acids of the antigen and the receptor, along with both any emergent negative/positive cooperative role in binding affinity, and any potential entropic concerns, is essential for the successful development of unnatural amino acids for treatment. High binding affinities are required to outcompete the natural antigenic peptide, and incorporating residues which contain stabilizing non-covalent interactions (i.e., H-bonding, $\pi \cdots \pi$, and $\mathrm{X}-\mathrm{H} \cdots \pi$ interactions) are essential, but many of the binding events are emergent phenomena arising from co-operativity effects including a number of 
adjacent residues on both receptor and peptide. Consequently, an in-depth knowledge of the receptor pockets (i.e. their size, shape, and charge distribution) is absolutely necessary for the rational design of new unnatural amino acids. Many studies have attempted to improve binding affinity by substituting these anchor residues for other amino acids (single mutations, double mutations, alanine scans, randomized libraries, etc), but they have primarily focused on natural amino acids and few have utilized unnatural amino acids. ${ }^{20}$

Another key aspect in a successful therapy is modulation of T-cell activation. A highaffinity HLAB may simply elicit an increased immune response, and it is essential to prevent this. This is where the HLABs and APLs differ: the APLs, through the modification of residues interacting with the T-cell, seek to modulate the immune response and recruit anti-inflammatory Th2 cells rather than pro-inflammatory Th1. HLABs seek to modify the T-cell face to prevent Tcell interaction at all. To achieve this goal, strategies including the incorporation of blocking residues, cyclizations, and crosslinking agents have been explored.

Central to all of this work is the use of new unnatural amino acids, and there are isolated examples employed for the different MHC Type II conditions. The purpose of this current review, organized by disease state rather than amino acid structure, is to consider the efforts to date using unnatural amino acids for the treatment of MHC Type II disorders as a whole rather than as isolated examples. The variety of methods used for creating these residues, and the challenges of integrating them into peptides, are readily generalizable from any specific disease to all the various conditions.

\section{Celiac Disease}

Celiac disease is characterized by a lifelong sensitivity to gluten proteins found in wheat, barley and rye known as gliadins, hordeins and secalins respectively. It affects approximately $1 \%$ of the western population and the number of those affected is expected to increase. ${ }^{21}$ Ingestion of gluten causes an immune response that damages the intestinal tract resulting in chronic diarrhea, malabsorption (causing anemia and vitamin/mineral deficiencies), and a host of related complications. Currently the only treatment option available is a gluten free diet, which can be difficult to maintain. ${ }^{22}$ 

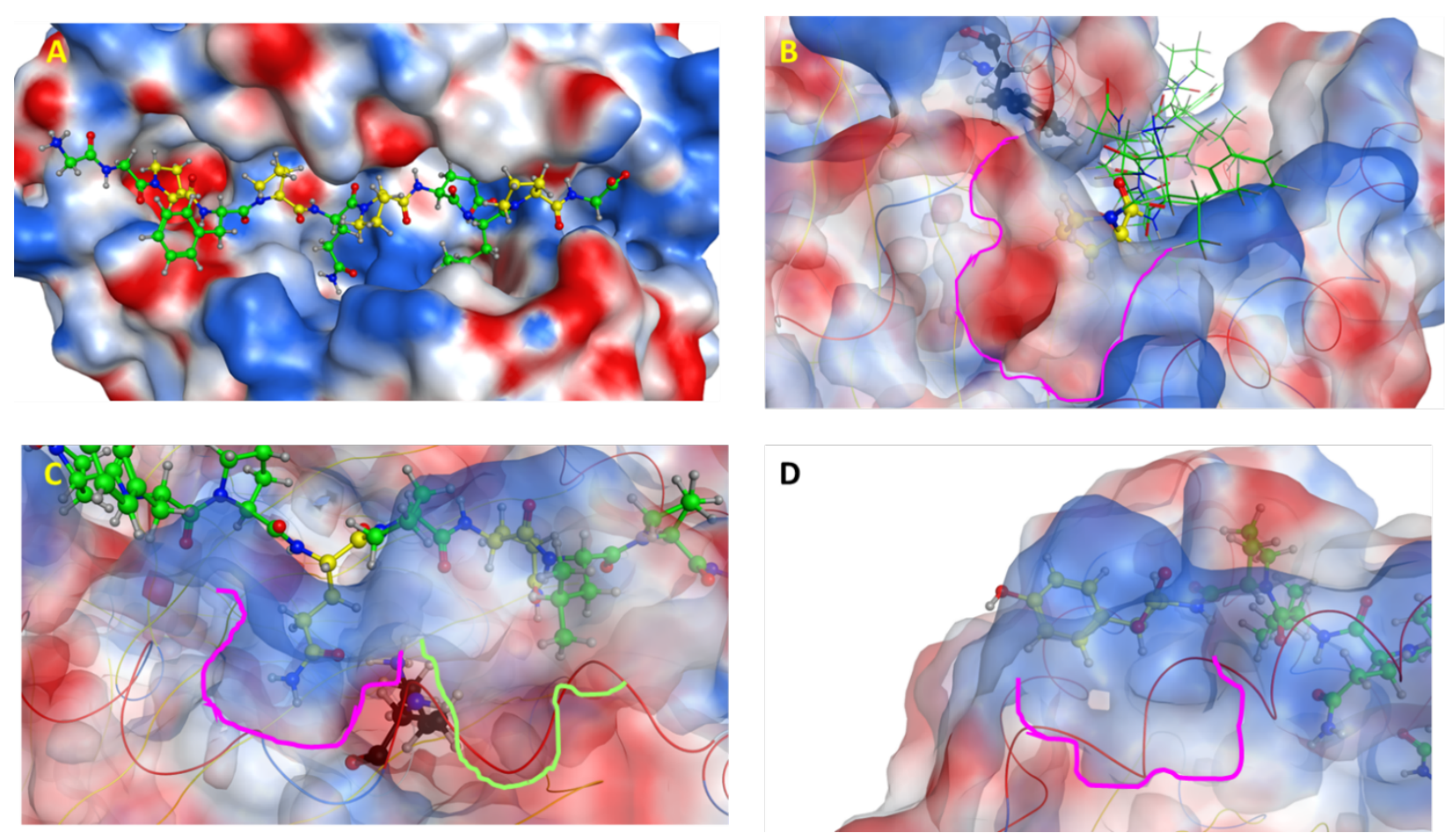

Figure 2. Energy minimized molecular models derived from the crystal structures ${ }^{23}$ of the pockets of interest; the surface represents the HLA (HLA-DQ2), while the $\alpha$-gliadin, LQPFPQPQLPY, is represented by the green peptide. A) Overall view of the binding groove with the prolines of the antigen highlighted in yellow. B) Expanded view of the P1 pocket. The mutated Phea53 residue is highlighted in black. In other members of this class it is an arginine, and it extends through the P1 pocket (outlined in pink), blocking it. C) Expanded view of the P4 (pink outline) and P6 (green outline) pockets. The Lys $\beta 71$ residue that separates the two pockets is highlighted in black, while the two glutamine residues that occupy (in the case of p6, poorly) are highlighted in yellow. D) Expanded view of the large, empty, p9 pocket (outlined in pink) partially occupied by tyrosine.

The majority $(>90 \%)$ of patients express allele HLA-DQ2, while a small portion are carriers for HLA-DQ8 (5\%). The epitope recognition preferences of these two receptors have been thoroughly studied and are well understood and crystal structures of the receptor bound to gliadin have been isolated. Gluten peptides are rich in proline and glutamine residues. High proline content also results in increased peptidase resistance allowing them to avoid degradation and reach the intestinal tract. Gluten peptides are then recognized by tissue transglutaminase (TTG) which is capable of deamidating gluten peptides resulting in gliadins which have increased affinity to the HLA receptor (due to their negative charge) and increased T cell response. ${ }^{24}$ It is however, possible in certain cases for HLA-DQ2 to recognize natural gluten peptides, though they are more often recognized in their deamidated form as gliadins. ${ }^{25}$ TTG has been shown to participate in wound healing and apoptosis. It is no surprise then that it is upregulated in inflamed intestinal tissues. It has been proposed that a viral infection or other environmental factors causing inflammation trigger TTG. This leads to deamidation of the gliadins present in any wheat-rich diet and onset of $\mathrm{CD}^{26} \alpha$-Gliadin, both the $17 \mathrm{mer}$ and 33mer, containing the sequence LQPFPQPQLPY, is the immunodominant peptides (Crystal structure, 1S9V; Figure 2) ${ }^{23,27}$ though many other HLA-DQ2binding peptides are also capable of triggering an immune response. ${ }^{28}$ The $33 \mathrm{mer}$ peptide is 
particularly immunogenic due to high protease resistance and the presence of six overlapping binding epitopes. Trying to target the antigen is challenging as there are many potential antigens. Trying to interfere with the downstream immune response, i.e. using NSAIDs or corticosteroids, is the acute treatment but is only partially effective and leads to a general depression of the immune system, increasing susceptibility to infection. New therapeutic approaches are required and APLs and HLABs have shown promise. Many of these have used unnatural amino acids to improve affinity or prevent $\mathrm{T}$-cell recognition.

Whenever unnatural amino acids are to be used, it is essential to have an understanding of the fundamental interactions of the natural antigen. For the purposes of this review, we will provide a more detailed analysis of the DQ2 receptor to illustrate the point. ${ }^{23}$ For other diseases, we will direct the reader towards the initial crystal structure and computational reports. The HLA-DQ2 receptor has a large pocket at $\mathrm{p} 1$. Due to a mutation Arg $\alpha 53$, normally conserved in other DQ molecules and forms hydrogen bonds as a key anchor residue, is missing in the p1 pocket. Its absence makes the pocket far larger, and allows for the incorporation of a proline in the $\mathrm{p} 1$ position. ${ }^{27}$ Proline residues can also be incorporated at $\mathrm{p} 3, \mathrm{p} 5, \mathrm{p} 8$ and $\mathrm{p} 9$. Glutamic acid, the result of TTG activity, is preferred in positions 4 and 6 as negatively charged residues form favourable interactions in these positions (Figure 2). A mutation results in the replacement of the blocked Tyr30 $\beta$ normally found in the DQ p6 pocket with serine, resulting in a pocket capable of hydrogen bonding. Nearby Lys $\beta 71$ results in preference for negative charges and nearby Tyr9 $\beta$ also participates in hydrogen bonding; this complex is perfect for a negatively charged residue such as Glu. ${ }^{23} \operatorname{Arg} \beta 70$, Asn $\alpha 62$ and Asn $\alpha 11$ were found to form important interactions in $\mathrm{p} 4$. It was also noted that the formation of attractive van der Waals interactions are important for interactions using $\mathrm{p} 1, \mathrm{p} 4$, and $\mathrm{p} 7$; while the residue at $\mathrm{p} 9$ was less important in the natural antigen as the pocket is so large that occupying residues do not form strong interactions with the receptor. Prolines at positions 5 and 8 face away from the HLA, making them suitable for modifications that affect $\mathrm{T}$ cell recognition (Figure 2). ${ }^{29}$ 

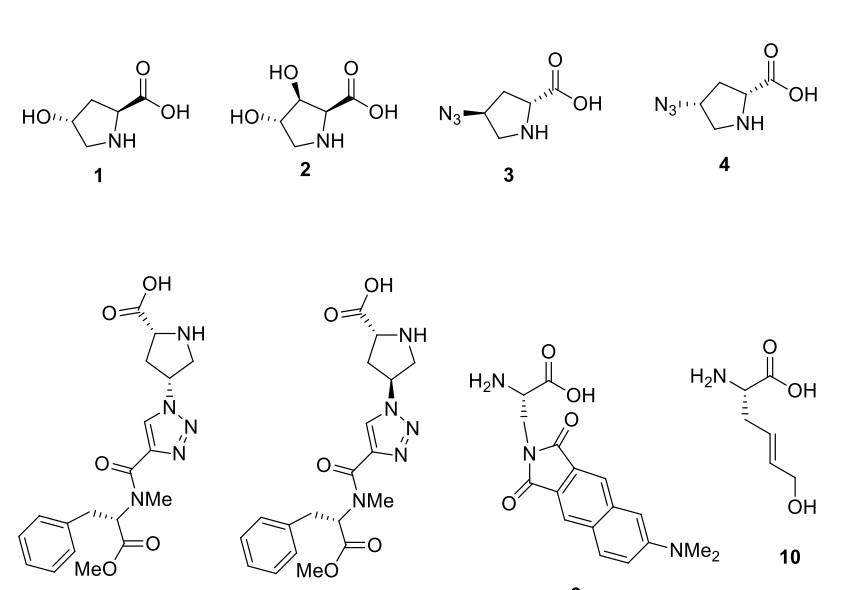

7

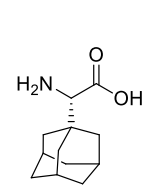

13

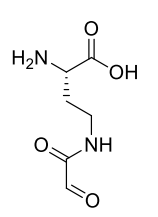

34

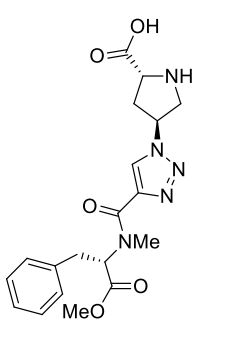

8

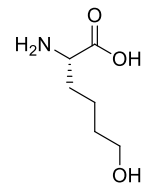

14

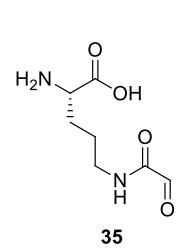

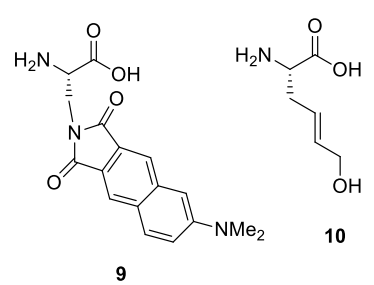

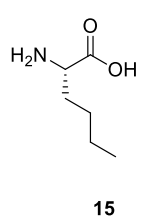

15

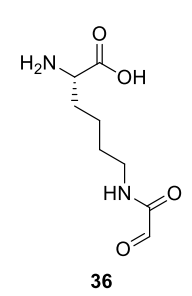

16
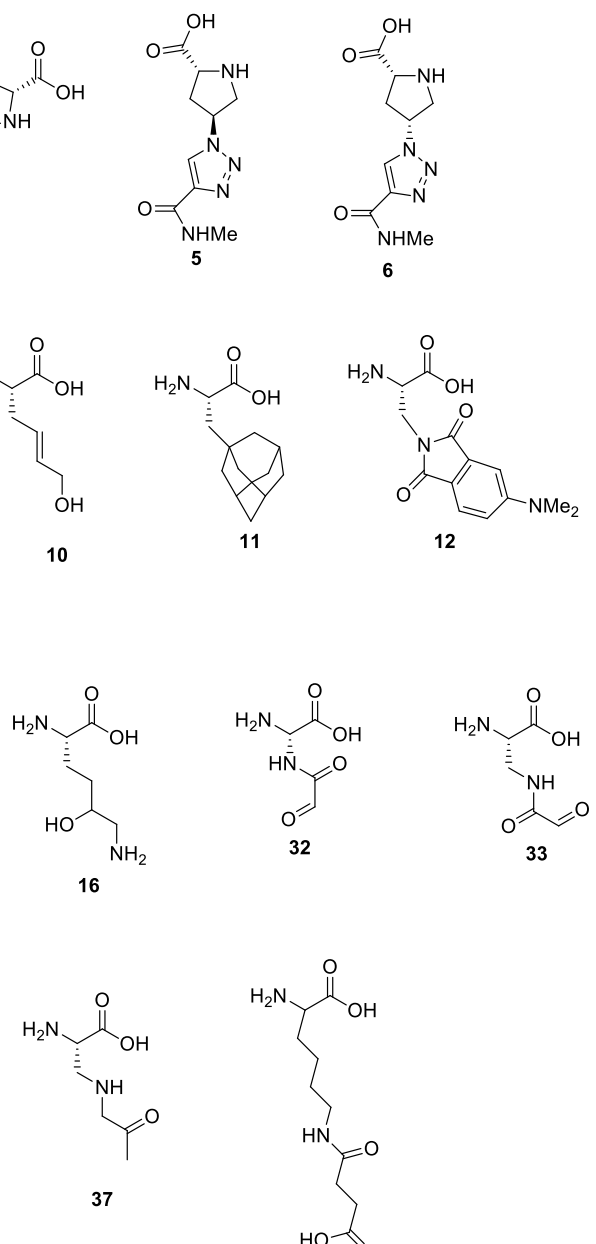

Figure 3. Unnatural amino acids utilized in the development of APLs and HLABs for CD.

In one study, hydroxyproline or dihydroxyproline $(\mathbf{1}, \mathbf{2} ;$ Figure 1$)$ residues were introduced into the $\alpha$-gliadin peptide to reduce the binding affinity of gluten. ${ }^{29}$ The aim was to develop a low affinity peptide which could then be genetically incorporated into wheat. These modifications can be achieved both enzymatically and chemically. The hydroxyproline peptides were studied computationally and it was found that substituting the prolines at positions 5 and 8 slightly improved binding as they formed better interactions with water. Expanding on this work, Kapoerchan and coworkers used azidoproline to suppress $\mathrm{T}$ cell responses..$^{30}$ (4S)-4-azido-Lproline (3) or (4R)-4-azido-L-proline (4) were introduced at p3 and p5. ${ }^{31}$ To further improve their T-cell blocking activity, they could be readily functionalized post-peptide synthesis using copperassisted azide-alkyne cycloaddition (CuAAAC) chemistry. These azides can be functionalized with various functional groups such as $N$-methylacrylamide or $N$-acryl-L-phenylalanine methyl ester resulting in amino acids 5-8. Most modified peptides had approximately the same binding affinity to HLA-DQ2 as the unmodified version however, one case resulted in drastically reduced binding, which was potentially due to the presence of steric clash between the peptide and HLA receptor. These modified peptides showed reduced $\mathrm{T}$ cell stimulation with larger substituents showing the lowest $\mathrm{T}$ cell stimulation. This illustrates that blocking $\mathrm{T}$-cell recognition is a potentially viable approach in the prevention T-cell stimulation. However, when studied in a 
competition assay, the peptides did not have sufficiently high binding affinity to outcompete gliadin and prevent $T$ cell activation.

To address this issue, the same team undertook another study to create a high affinity gliadin analog. ${ }^{32}$ In this study they took the peptide FVAEYEPVL which was predicted to be a strong HLA binder and tested N-terminal extensions and single amino acid substitutions. Their results showed the ADA extension increased binding affinity 5-6 fold while the best binder after amino acid substitution was found to be ADAYDYESEELFAA. They then used unnatural amino acids at $\mathrm{p} 1$. The $\mathrm{p} 1$ pocket is large and hydrophobic, and as mentioned above, natural amino acids are incapable of completely filling this pocket. Eight unnatural amino acids (structure 9-16; Figure 3) were designed, synthesized, and incorporated into the P1 position in place of the tyrosine. Many of these molecules had been previously prepared, but several of the syntheses are noteworthy.

The fluorescent derived amino acid $N_{\alpha}-$ Fmoc- $N_{\beta}-(6-N, N$ '-dimethyl-aminonaphtalimidoyl)L-diamino-propionic acid (6-DMNA) (9) was selected as its increased bulk could provide a good fit and consequently improve binding. This amino acid was synthesized using 3-nitrobenzaldehyde (17; Scheme 1) as the starting material. Protection of the aldehyde 18 was followed by nucleophilic substitution with chloromethyl phenyl sulfone to provide 19. Deprotection, and addition of diethyl maleate allowed for the in situ cyclization and elimination of the phenylsulfone provides the diester 20. Reductive amination of the nitro group to the amine 21, followed by saponification of the ester functionality to allow for anhydride formation provides electrophile 22. The anhydride was then treated with the diaminopropanoic acid derivative $\mathbf{2 3}$ (derived from serine) ${ }^{33}$ to provide maleimide 24. Finally, removal of the allyl ester provides the Fmoc-protected amino acid 25, the protected derivative of 9 , which is suitable for solid-phase synthesis.

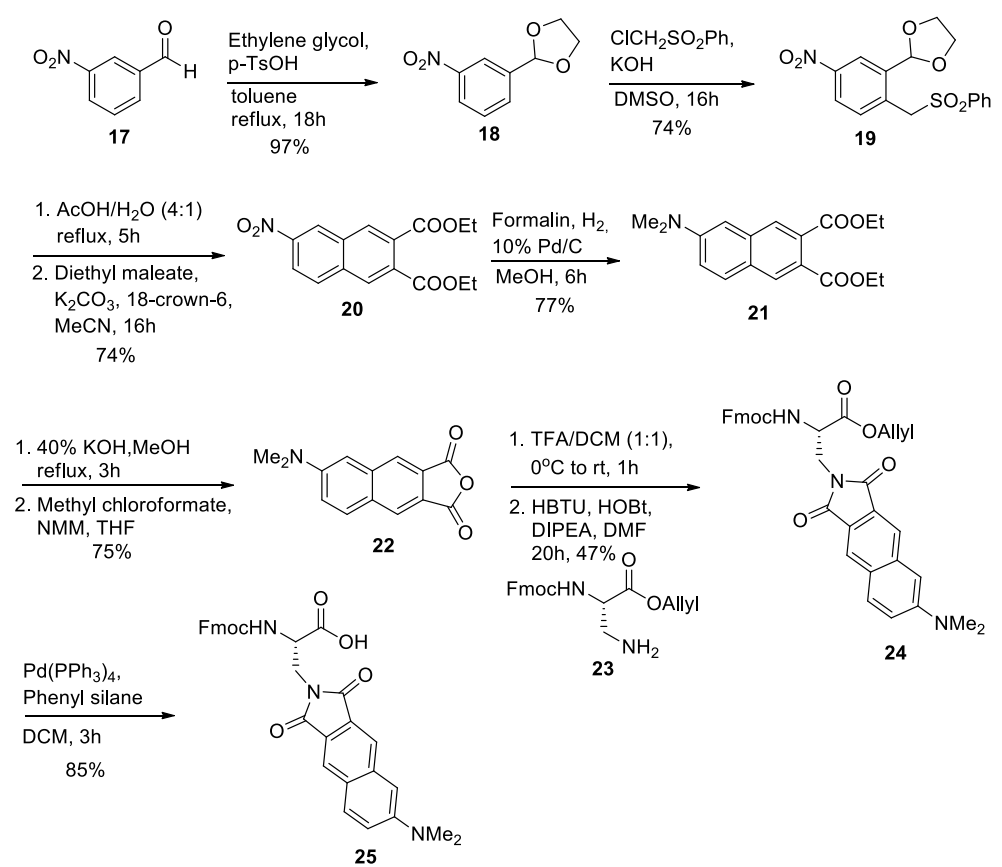

Scheme 1. Synthetic procedures for the synthesis of fluorescent Fmoc 25, the protected analogue of amino acid 9. 
Lysine is a large residue, and consequently acts as an excellent platform for elaboration for filling the $\mathrm{p} 1$ pocket. To prevent the repulsion of a positively charged side chain amino acid with the charged His side chain located on the wall of the pocket, a neutral hydroxyl analogue (10 in Figure 3) was designed (Scheme 2). Oxidation of the primary alcohol of protected L- homoserine 26 provided aldehyde $\mathbf{2 7}$. Wittig olefination with hydroxylated reagent $\mathbf{2 8}$, resulted in the formation of aldehyde 29. Subsequent 1,2 reduction and concomitant transesterification generated ethyl ester 30. Saponification of the ester provided the de-protected Boc-building block 31. Replacing the Boc group with an Fmoc group for the required SPPS strategy completes the synthesis of 10a.
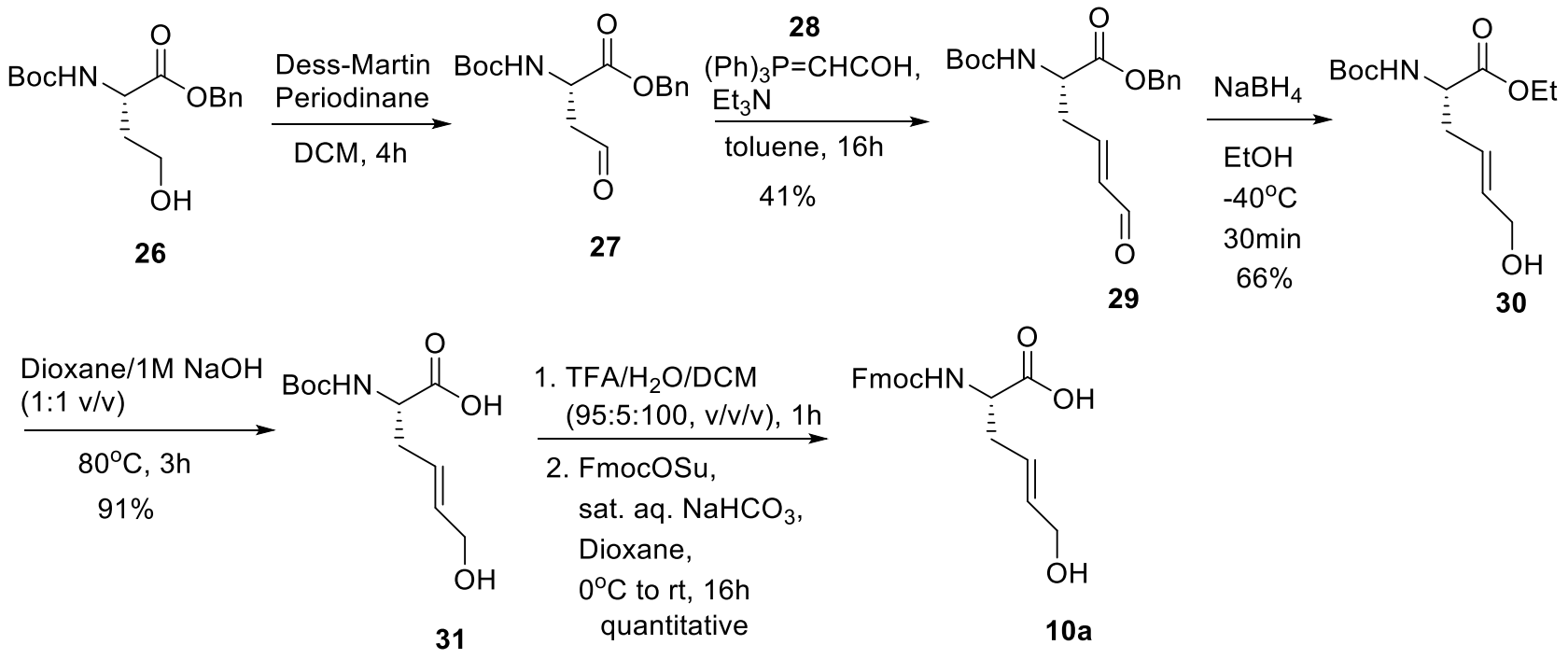

Scheme 2. Synthesis of the Fmoc derivative, 10a, of hydroxylated lysine analogue 10.

In general, using bulkier, and/or charged residues takes advantage of the formation of stabilizing interactions that are unavailable to the natural residues and was found to increase binding affinity by factors of 4-5. The incorporation of unnatural amino acids is a promising approach for increasing the binding affinity of peptides. However further increases in binding affinity require careful design as the gains using this trial-and-error approach are modest.

Another study by Siegel and coworkers modified the $\alpha 1$-gliadin peptide to incorporate aldehyde bearing amino acid derivatives (32-36; Figure 3) in the p4 and p6 positions. ${ }^{34}$ These aldehyde derivatives are capable of reversibly condensing with Lys $\beta 71$ located near the p4 and p6 positions to form an imine. They found when the appropriate length aldehyde $\mathbf{3 3}$ was employed, binding affinity to the DQ2 increases and the dissociation half-life increases by a factor of eight compared to the unmodified peptide. As expected, either mono-aldehyde peptide also had a much higher degree of T-cell activation due to their more stable occupation of the HLA receptor. The dialdehyde substituted peptide, however, decreased T-cell stimulation, which was proposed to be a result of the structural changes induced on the T-cell binding face due to the mutated residues. Exploiting this behavior, they then modified the peptide to act as a HLAB based on their previously reported work. ${ }^{35}$ This involved replacing two solvent-exposed leucine residues with succinylfunctionalized lysine moieties 38. This new peptide, however, was less effective at preventing Tcell activation despite the incorporation of imine-forming residues (ketones and aldehydes 32-38). It would be interesting to investigate the biological behaviour of the potent DQ2-binding monoaldehyde peptides functionalized with the blocking residues. The longer half-life and increased 
binding affinity would potentially assist the peptide to outcompete gliadin and prevent $\mathrm{T}$ cell proliferation.

The aldehydes (33-36) used in this report were synthesized starting from an Fmoc protected lysine homologue incorporated in a peptide chain using Boc SPPS (39; Scheme 3). The Fmoc protecting group was cleaved using $20 \%$ piperidine to yield free amine $\mathbf{4 0}$. This side chain nitrogen was capped by coupling an Fmoc protected serine residue to the free amine using HBTU to generate 41. SPPS can then be continued. Following cleavage from the resin support, the Fmoc protecting group was removed $(\mathbf{4 3})$ and then the peptide was treated with sodium periodate at $\mathrm{pH}$ 7 in a phosphate solution to produce glyoxamide $\mathbf{4 4}$.
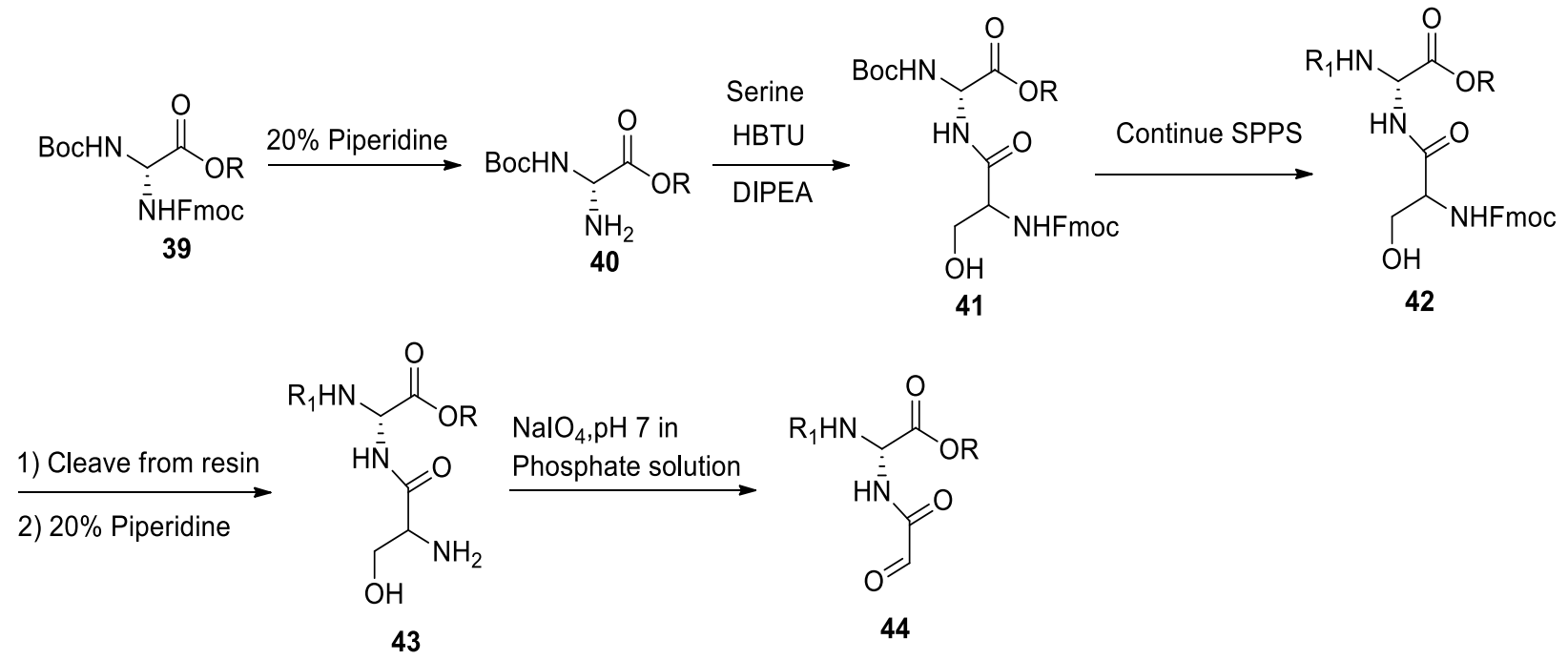

Scheme 3. Synthesis of glyoxamide-functionalized amino acid $\mathbf{4 4}$ from diamino ethanoic acidderived residue $39 .{ }^{34} \mathrm{R}$ and $\mathrm{R}_{1}$ represent peptide chains or hydrogen if the residue is at the end of the chain.

In two HLAB studies conducted by Xia and coworkers, three different T-cell inhibitory mechanisms were investigated. ${ }^{35-36}$ The first incorporated the same bulky blocking groups in the $\mathrm{p} 5$ and $\mathrm{p} 7$ positions: lysine residues modified with succinyl moieties $(\mathbf{3 8}) .{ }^{35} \mathrm{~A}$ dimeric version of the unmodified peptide was then synthesized by cross-linking lysine residues in $\mathrm{p} 7$ using a hexaethylene glycol linker. The binding of the succinyl peptides was comparable to the unmodified peptide, but the dimeric peptide had higher affinity. The dimeric peptides form complexes with two DQ2 molecules simultaneously; but, this is only observed at $\mathrm{pH}$ 5.5. Neither the blocking nor the dimeric peptides elicited a $\mathrm{T}$ cell response, and were both even found to be able to competitively inhibit T-cell proliferation in the presence of antigenic peptides in a dose dependent manner.

The second study focused on the synthesis of these dimeric and cyclic peptides. ${ }^{36}$ Dimeric peptides which were synthesized using thiol-maleimide bonds were unable to prevent $\mathrm{T}$ cell proliferation. Two types of cyclic peptides were then tested, one in which the core peptide is flanked by a glycine spacer and then linked via disulfide bond or ones in which there is an internal cyclization using internal lysine residues and polyethylene glycol linkers. These peptides had similar or slightly better binding than the reference peptide. The disulfide peptides again did not inhibit $\mathrm{T}$ cell activation while two of the PEG based peptides which used a longer gliadin epitope did effectively inhibit $\mathrm{T}$ cell proliferation. The discrepancy is potentially due to the in situ reduction 
of the disulfide bond, cleaving the cycle. Although the binding was deemed insufficiently potent to act as a true HLAB, it is an excellent proof-of-concept. Combining both dimerization and cyclization along with increasing peptide-MHC affinity through modifications of anchor residues may provide an effective therapeutic approach for celiac disease and other MHC type II conditions in the future.

\section{Rheumatoid Arthritis}

Rheumatoid arthritis is the chronic inflammation of the joints caused by an autoimmune response to the synovium (lining of the joints) which eventually leads to cartilage destruction, bone erosion, and loss of joint function. ${ }^{37}$ While it is most commonly associated with joint damage, RA can also cause complications of the skin, eyes, lungs and heart among other organs and structures. 41 of every 100,000 people will be diagnosed with RA. There is no cure and current treatments focus on reducing inflammation and preventing disease progression and subsequent join damage. Many of the drugs that are used to slow progression of the disease modulate various components of immune system activation or inflammation pathway which results in side effects such as an increased risk of infection. ${ }^{38}$

The main genetic factors associated with RA are the HLA receptors HLA-DR1 and HLADR4. The disease etiology is unknown although several potential antigens including proteoglycan, gp39 and type II collagen have been associated with disease onset. Collagen-induced arthritis is the most widely used model in the study of RA. The $\mathrm{CII}_{250-270}$ sequence is highly immunogenic, and $\mathrm{CII}_{263-272}$ is currently believed to be the immunodominant peptide and is recognized by both HLA-DR4 and DR1 molecules. ${ }^{39}$ Residues p1 263F and p2 264K were found to be key anchor residues for HLA-DR binding while residues p5 267Q and p9 270K are the key TCR contact residues (Figure 4). ${ }^{40}$
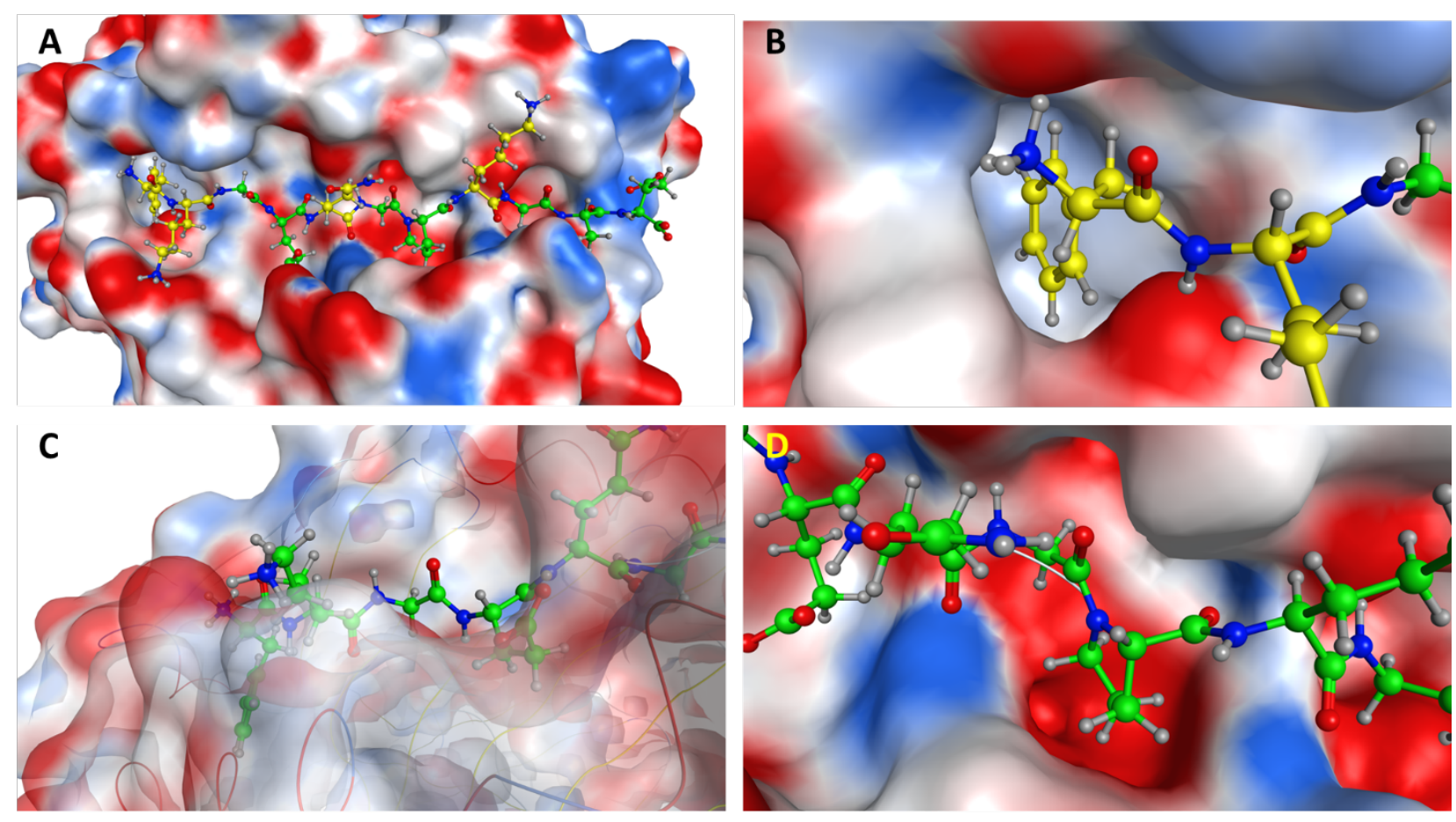
Figure 4. Crystal structures ${ }^{39 a}$ of the pockets of interest (energetically minimized); the surface represents the HLA-DR4, while the $\mathrm{CII}_{263-272}$ peptide is represented by the green peptide. A) Overall view of the receptor with the key anchoring residues highlighted in yellow. B) Expanded view of the P1 pocket showing the incomplete fit of a flat Phe. C) View of the P4-6 region highlighting the importance of backbone-receptor hydrogen bonds to orient the system. D) Highlight of the $\mathrm{P} 9$ pocket showing the incomplete filling of the electropositive surface by the proline residue.

Modifications using natural amino acids have been extensively studied and have shown promise in inhibiting $\mathrm{T}$ cell activation. This has been most successfully used to substitute the TCR contact residues to generate APLs that modulate the response into an anti-inflammatory mode. ${ }^{41}$ One early study into the use of APLs focused on editing the epitope of the $\mathrm{CII}_{245-270}$ peptide to develop a competitive binder. ${ }^{42}$ This peptide is a major $\mathrm{T}$ cell determinant in I-A ${ }^{\mathrm{q}}$ mice. Key residues required for T-cell stimulation were substituted with others based on the type I collagen epitope (245-270) which naturally contains hydroxyproline residues. One promising peptide ( $\mathrm{I}_{260}$, $\mathrm{A}_{261}$, and $\mathrm{F}_{263}$ to $\mathrm{A}_{260}$, hydroxyproline 261 and $\mathrm{N}_{263}$ ) reduced $\mathrm{T}$-cell stimulation and decreased cytokine production, even when tested in a competition assay with the immunogenic $\mathrm{CII}_{245-270}$. This observation indicates that it is able to competitively bind to the HLA, and that the mutations likely affect TCR contact mode as expected.

In a study by Falcioni and coworkers, unnatural amino acids (45-73; Figure 5) were substituted for both MHC anchor residues as well as TCR contact residues based on computational modeling to generate heptapeptides. ${ }^{43}$ 

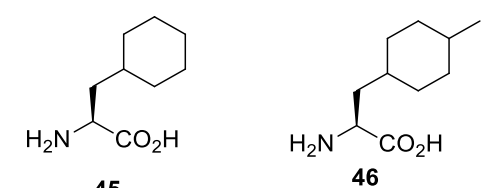

45<smiles>NC(C(=O)O)C1CCCCC1</smiles><smiles>CC(=O)NCSCC(N)C(=O)O</smiles><smiles>O=C(O)C1Cc2ccccc2CN1</smiles>

57
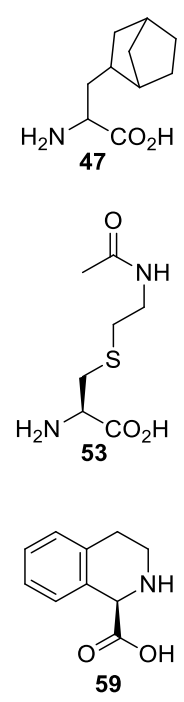

59

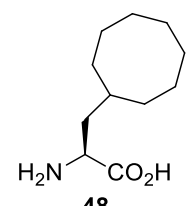<smiles>CCC(C)C(N)O</smiles>

49<smiles>Cc1ccc(C(N)C(=O)O)cc1</smiles><smiles>CC(=O)NC(CS)C(=O)O</smiles>

55<smiles>CCCCC(N)C(=O)O</smiles><smiles>O=C(O)C1NCCC1c1ccccc1</smiles><smiles>CC(C)(C)C(N)C(=O)O</smiles><smiles>NC1CCc2cccc3c2C(C(=O)O)C(=O)C31</smiles>

63<smiles>NC1CCC(=O)N2CCCC(C(=O)O)N2C1=O</smiles><smiles>CC(C)C[C@H](N)CO</smiles><smiles>OC[C]1CCCCN1</smiles>

66<smiles>CC(=O)NCCCC=O</smiles><smiles>CC(=O)NCCC=O</smiles>

68<smiles>[Y]O[C@H](N)[C@@H](N)c1[X]cc(C(=O)O)n1</smiles><smiles>[Y6]NC(Cc1cccc([X])c1)C(NC(=O)O)C(=O)O</smiles><smiles>CN(C)CCCCC(N)C(=O)O</smiles>

69

70<smiles>[X]C1CCN(C(=O)O)C(C(=O)O)N2CCC(N)C(C)C12</smiles><smiles>NC1CC[C@H]2SCC(C(=O)O)N2C1=O</smiles><smiles>NC1CC[C@H]2CCC(C(=O)O)N2C1=O</smiles>

77<smiles>NC1CCC(=O)N2CC=CC(CO)C2C1=O</smiles><smiles>NC1Cc2ccccc2CN(CC(=O)O)C1=O</smiles>

Figure 5. Unnatural amino acids used in the development of APLs for RA.

The aim was to create HLABs: improve HLA binding, inhibit TCR recognition and increase peptide stability. Anchor position p1 was found to have a preference for large cyclic residues (Tyr, Phe, Trp) in the case of DR1 and several DR4 alleles which preferred simpler aliphatic chains (Ile, Leu, Val). To make a general candidate, cyclohexyl alanine (45; Figure 5) was incorporated in this position along with the slightly larger residues (46-48). The canonical residues Met, Ser, and Leu were found to be optimal for p4, p6, and p7 respectively. The research team also probed the importance of backbone hydrogen bond formation using N-methylated derivatives of the amino acids. Hydrogen bonds formed by the amide bonds of the residue at 
position p2 and p4 were found to be essential for peptide binding, and loss of these H-bonds resulted in a several hundred-fold decrease in affinity. In contrast, N-methylation at either p3 or p5 had little to no effect on binding affinity but greatly increased resistance to protease degradation. None of the unnatural amino acids (49-51) examined at $\mathrm{p} 2$ improved the binding affinity compared to Arg: the backbone hydrogen bond is critical for binding and changes in the backbone structure are not tolerated. There is a small hydrophobic pocket near p3 which the authors attempted to exploit using residues 52-59. These compounds increased binding affinity of the peptide. Due to the importance of the $\mathrm{p} 4$ hydrogen bond, this position was sensitive to substitution, and only $\mathbf{4 5}$ and 60 were useful; for $\mathrm{p} 7$, residue $\mathbf{6 2}$ was found to provide a useful increase to binding affinity. There is significant diversity in this library, and the synthesis of these amino acids can prove instructional.

Unnatural amino acids are often considered a recent area of exploration, but the field stretches back to the beginning of modern synthesis. ${ }^{\mathrm{t}}$-Butyl derivative $\mathbf{6 2}$ was first prepared in 1914, ${ }^{44}$ using pinacolone (74; Scheme 4) as the starting material. Under alkaline conditions, permanganate oxidation yields trimethylpyruvic acid 75. Condensation of the acid with hydroxylamine generates oxime $\mathbf{7 6}$ that was reduced using zinc dust/acetic acid to amino acid $\mathbf{6 2}$. Enantiospecific approaches to the same target, with higher yields, have also been more recently developed. ${ }^{45}$

Scheme 4. The first reported synthetic protocol for $\mathbf{6 2} .{ }^{44}$

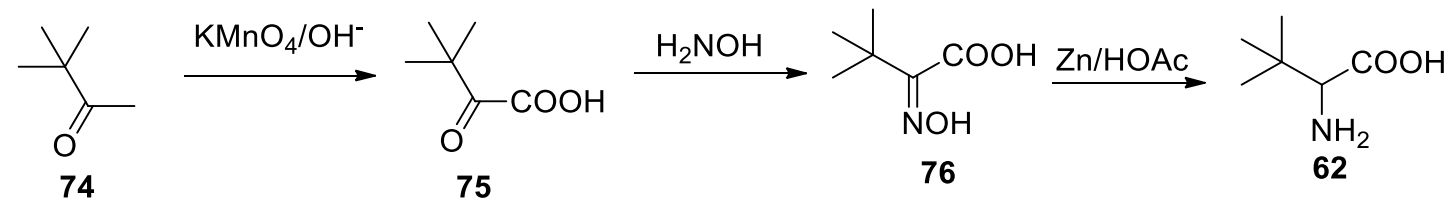

Unfortunately, despite this significant synthetic effort, a peptide comprising mostly natural amino acids (except for $\mathbf{2 4}$ in p1) showed the best binding to all DR4 alleles; however, this peptide was also highly susceptible to proteolysis. Inhibition studies showed that several of the synthetic APLs proved to be good antagonists, despite their lower affinity, when tested in conjunction with immunogenic peptides; but, 50\% inhibition required a roughly 20:1 ratio of HLAB to natural antigen. One interesting result arising from this work is the reminder that binding affinity does not directly translate into inhibition as other factors, such as cellular uptake and degradation resistance, contribute greatly to immunological outcomes. Consequently, peptides with lower binding affinities may prove to be much better overall antagonists should they be more stable.

In a similar study which continued the work, dipeptide mimetics $(\mathbf{6 3}, \mathbf{6 4}, \mathbf{7 7 - 8 5})$ and glycoconjugates were incorporated into the design of a cathepsin (a peptidase) resistant, high affinity HLA-DR binder. ${ }^{46}$ The same preferred sequence motif described above was used as the baseline starting point for this study. An investigation into the importance of the peptide length revealed that as the peptide was truncated, affinity decreased. However, one tetrapeptide (Ac(Cyclohexylalanine)RMM-NH2, binding p1-p4) maintained a moderate binding affinity. This peptide was then extended by integrating a variety of non-amino acid compounds, such as sugars (i.e., Mannosamine) that can form interactions with the pockets of the HLA in place of the deleted amino acid residues. In the best cases, similar binding affinities to the parent peptide were 
obtained. Dipeptide mimetics $(\mathbf{6 3}, \mathbf{7 7 - 8 5})$ were incorporated in positions 2-3, 4-5, and 6-7 where peptide-receptor H-bonds form critical interactions; reducing the freedom of movement may improve binding. However, all of these dipeptide replacements result in lowering the affinity to the receptor due to unfavourable steric interactions, but all result in significantly improved peptidase stability and showed higher levels of T-cell inhibition. These studies highlight the complexity and non-trivial nature of the design of potential APLs.

Within the series, 7,6 bicyclic pyridizine, 9-aminooctahydro-6,10-dioxo-6H- pyridazino[1,2-a][1,2]diazepine-1-carboxylic acid (64 Figure 6) and a 5-amino-1,2,4,5,6,7hexahydroazepino[3,2,1-hi]indol-4- one-2-carboxylic acid (63 Figure 3) were found to be acceptable substitutes that maintain the required backbone H-bonds interactions at $\mathrm{p} 2$ or $\mathrm{p} 4$.

Compound 64 was synthesized via $\mathrm{N}$-acylation of the t-butyl ester of piperazic acid (87; Scheme 5) with a glutamic acid derivative $\mathbf{8 6}$ to provide $p s e u d o d i p e p t i d e ~ 88 .{ }^{47}$ Hydrogenolysis followed by an intramolecular $\mathrm{N}$-acylation provides the seven-membered ring. Deprotection of the maleimide unmasks the amine $\mathbf{9 0}$ and a final cleavage of the t-butyl ester provides the building block 64. The other members of this class were prepared in an analogous manner.

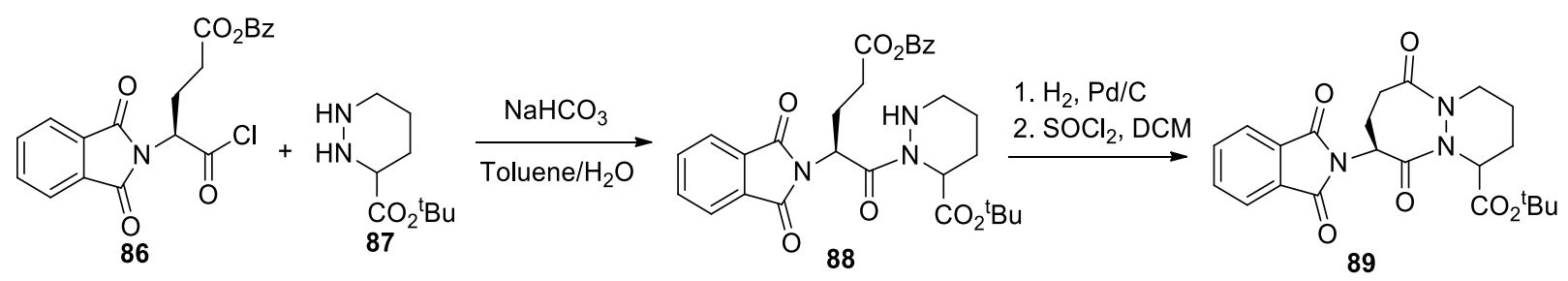<smiles>CCOC(=O)C1CCCN2C(=O)CCC(N)C(=O)N1C2C(=O)O</smiles>

Scheme 5. Synthesis of 7,6 bicyclic pyridizine, 9-aminooctahydro-6,10-dioxo-6H- pyridazino$[1,2-\mathrm{a}][1,2]$ diazepine-1-carboxylic acid $\mathbf{6 4}$. $^{47}$

An alternative class of dipeptides, exemplified by benzo-fused azepinone $\mathbf{6 3}$ were prepared through an intramolecular annulation. ${ }^{48}$ Indoline (92; Scheme 6) is acylated with the acid fluoride derivative of protected aspartic acid residue 91 to obtain ester 93. Hydrogenolysis leads to the formation of acid 94, which is selectively reduced and converted to the diethyl acetal 95 over three steps (thioester synthesis, Fukuyama reduction and conversion of the aldehyde to the acetal) to set up the key cycloannulation. Reaction of the acetal with polyphosphoric acid (PPA) generates unsaturated azepinone 96. Hydrogenation and subsequent removal of the phthalimido group leads to the formation of the required 7,5-fused azepinone $\mathbf{6 3}$. 

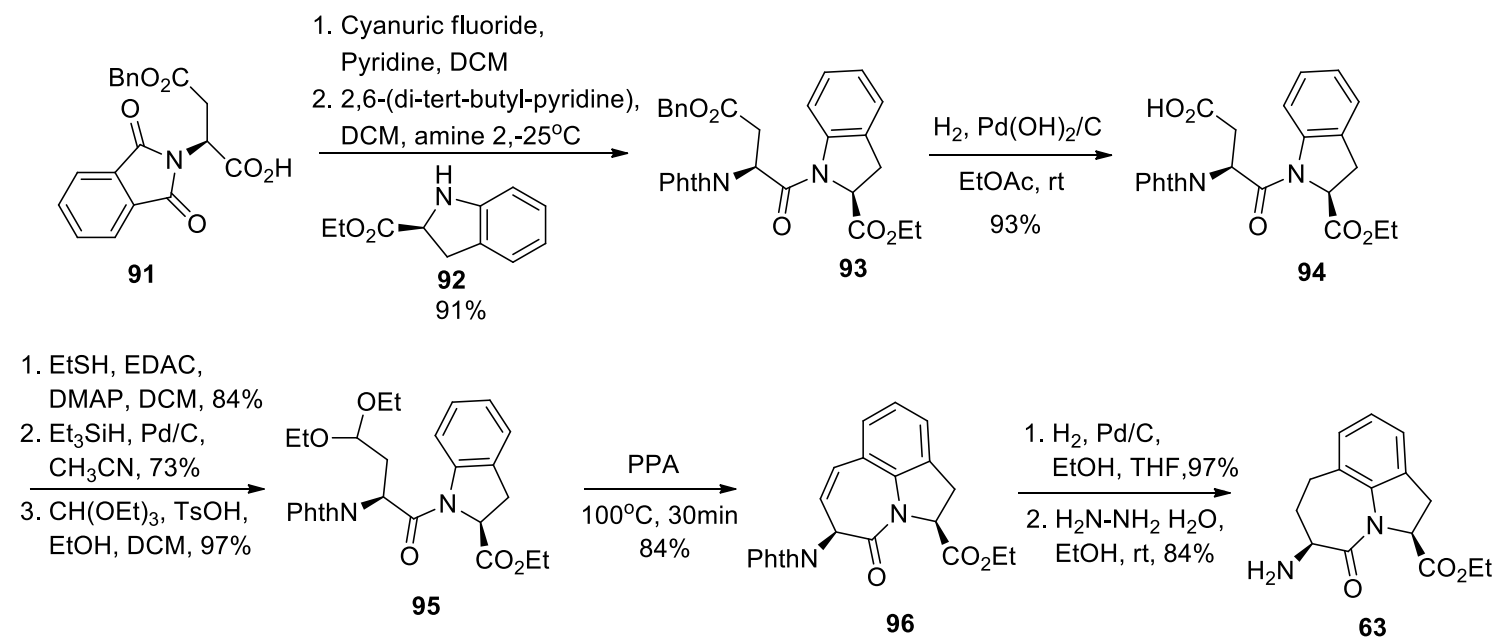

Scheme 6. Synthesis of benzo-fused azepinone $\mathbf{6 3} .{ }^{48}$

As an alternative to this approach, and to increase peptidase resistance, Andersson and coworkers introduced oxazoles (97-99; Figure 6) into the protein backbone, replacing vulnerable amide bonds in the $\mathrm{CII}_{259-273}$ peptide and formed oxazole-glycoprotein peptides (example glycofunctionalized amino acid 100). ${ }^{49}$ These peptides had low binding affinity for mouse $\mathrm{A}^{\mathrm{q}}$ but did bind DR4 (there is a difference in the alignment of the pockets). However, the DR4 binding peptides also elicited strong $\mathrm{T}$ cell response. The reasoning behind the low affinities is unclear but it may be due to the rigidity of the oxazolone moieties. To further increase stability of the previously synthesized APLs ${ }^{43}$ to plasma proteins in addition to the cathepsins, Rosloniec and coworkers incorporated both oxazolones and other unnatural amino acids into previously tested APLs (101-103, Figure 7). ${ }^{50}$ Arginine in p2 was replaced with 101 to prevent its recognition by tryptic peptidases and the Met resdiue was replaced with norleucine to inhibit T-cell recognition. These peptides maintained their high affinity for DR4 and could inhibit T-cell activation in a dose dependent manner and were found to be effective treatments in mouse models for RA. Residue 102 was incorporated because of its high hydrophobicity, which should allow for easier crossing of membranes and improve peptide uptake. The new peptides maintained their high binding affinity as well as their ability to inhibit $\mathrm{T}$ cell responses. The synthetic procedure for making compound $\mathbf{1 0 2}$ is interesting as it involves a de novo synthesis of an amino acids (Scheme 7). ${ }^{51}$ Acylaminomalonate (104) is condensed with cinnamaldehyde (103) under basic conditions to form a phenylproline analogue, 105. Silane-mediated deoxygenation provides the pyrrolidine 106, and following monosaponification, the unmasked acid is lost through decarboxylation (107). Deprotection provides amino acid 108, that is then coupled with enantiomerically pure $\alpha$ methylbenzylamide using EDC, allowing for resolution of the two diastereomers resulting in 109. 
Rigorous cleavage of both amide bonds under forcing conditions liberates the pure amino acid 102 that is protected as the Fmoc derivative for SPPS.

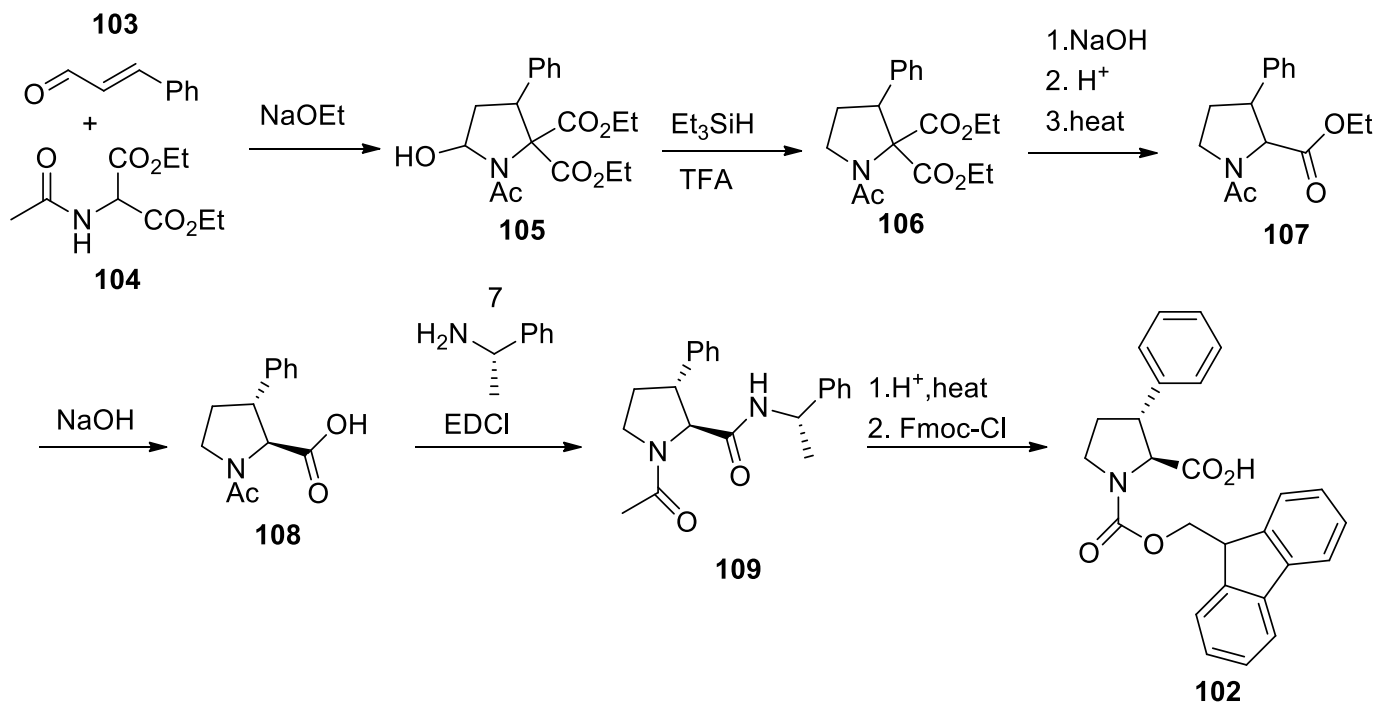

Scheme 7. Synthesis of proline derivative $\mathbf{1 0 2}$ from achiral starting materials through a late stage resolution. ${ }^{51}$

As mentioned, the peptides incorporating $\mathbf{1 0 2}$ also make use of achiral oxazole-based amino acids, and residue 99 is a typical example (Scheme 8). ${ }^{49}$ The synthesis begins with the deprotonation of Schiff base $\mathbf{1 1 0}$ using sodium hydride; the anion is quenched with phenylacetaldehyde. The imine is cleaved to provide the transient intermediate $\mathbf{1 1 1}$ that is isolated following coupling to glycine to generate dipeptide 112. Oxidation with Dess-Martin periodinane forms ketone 113, and cyclodehydration using triphenylphosphine, iodine, and triethylamine leads to the formation of functionalized oxazole intermediate 114. The deprotection of the Boc and $\mathrm{t}-\mathrm{Bu}$ groups with TFA followed by N-Fmoc protection generate final product 99a, the protected analogue of 99. The other members of this rotationally restricted and enzymatically-stabilized class of residues are prepared in an analogous manner.
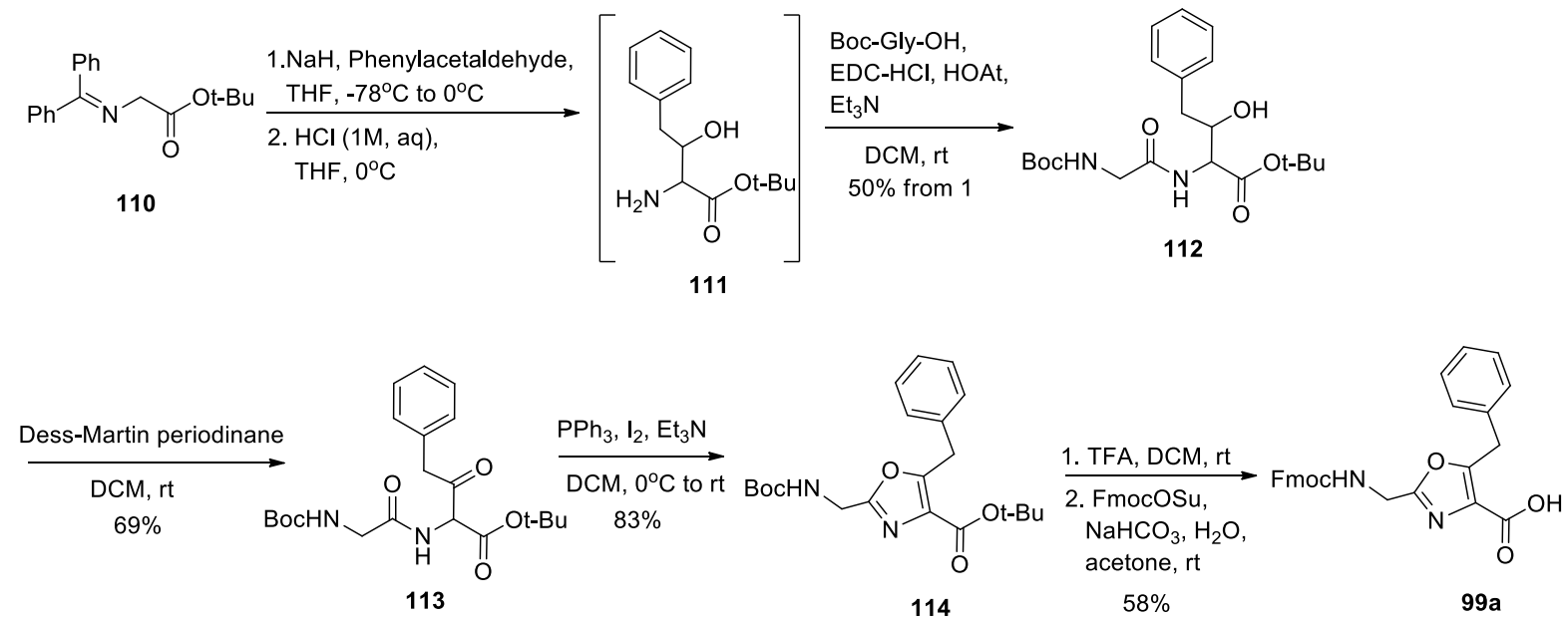
Scheme 8. Synthesis of Fmoc-protected oxazole derived amino acid 99. ${ }^{49}$

In stark contrast to the achiral 99 is carbohydrate amino acid 100. Glycoconjugates are common building blocks for glycoproteins, but using one as a multivalent hydrogen-bond donor/acceptor is a creative solution, and the connectivity is highly unusual for an O-linked glycoside. The synthesis (Scheme 9$)^{52}$ begins with the commercially available natural $(2 \mathrm{~S}, 5 \mathrm{R})-$ $(+)$-hydroxylysine dihydrochloride salt $\mathbf{1 1 5}$ being protected as the bis-Boc derivative using aqueous $\mathrm{NaHCO}_{3}$ and $(\mathrm{Boc})_{2} \mathrm{O}$. The acid is then chemoselectively protected with etherealdiazomethane to obtain the (2S,SR)-(+)-ester 116. A Helferich Koenigs-Knorr glycosylation provides the $\mathrm{O}$-glycoside 117. Alkaline hydrolysis, and final Boc deprotection results in formation of the unusual glycoconjugate $\mathbf{1 0 0}$.

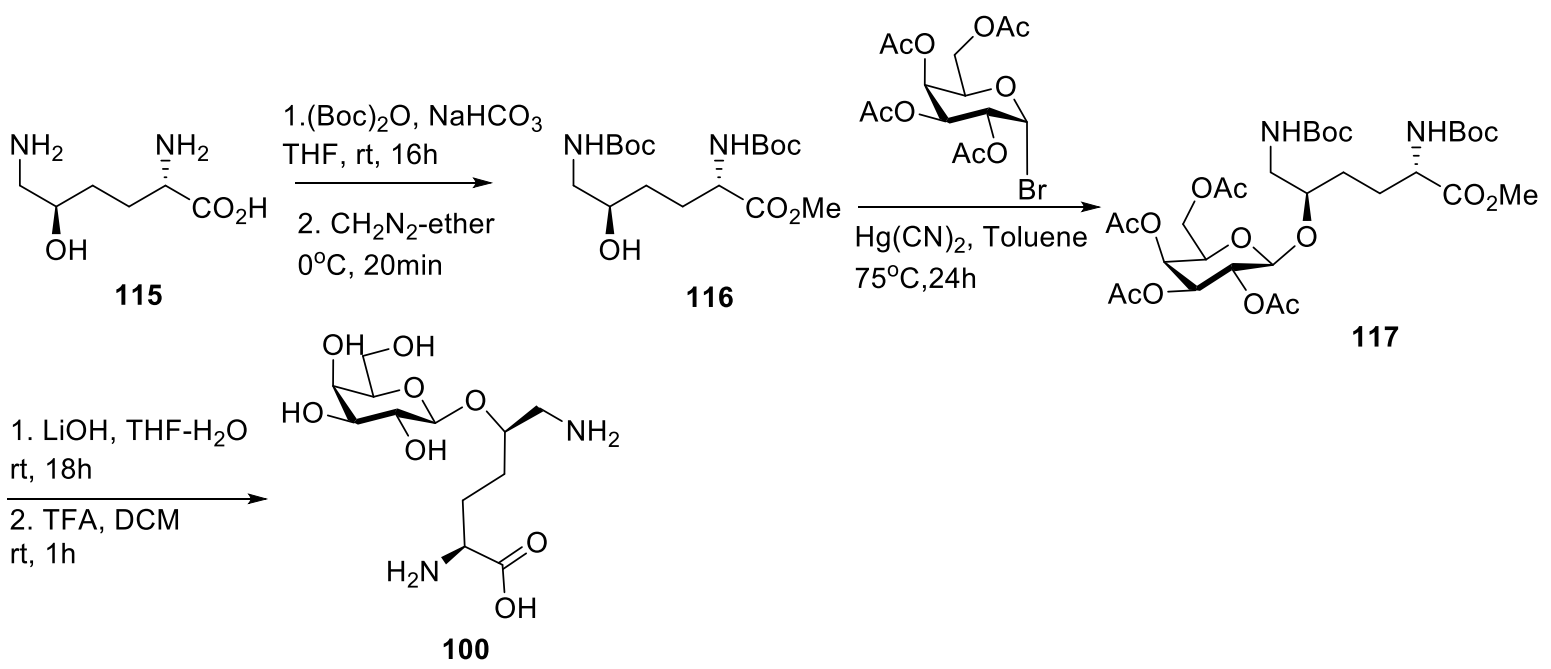

Scheme 9. The reported synthetic strategy for glycoconjugate 100.52

The above reports all focused on the collagen type II epitope, but other antigens associated with DR4 are also potential immunodominant sequences that can act as potential starting points for designing new therapeutics. Boots and coworkers focused on the generation of APLs using the gp39 $263-275$ epitope as the parent compound. ${ }^{53}$ The examples of unnatural amino acids used in APLs for the treatment of Rheumatoid Arthritis reported by Boots and coworkers (118-125) are provided in Figure 6. 
<smiles>CC[C@H](C)[C@H](N)c1nc(C(=O)O)co1</smiles>

97<smiles>N=C(N)N1CCC(C(N)C(=O)O)CC1</smiles><smiles>N[C@@H](CCc1ccccc1)C(=O)O</smiles>

118<smiles>N[C@@H](Cc1cccnc1)C(=O)O</smiles>

122<smiles>C[C@H](N)c1nc(C(=O)O)co1</smiles>

98<smiles>NCc1nc(C(=O)O)c(Cc2ccccc2)o1</smiles>

99

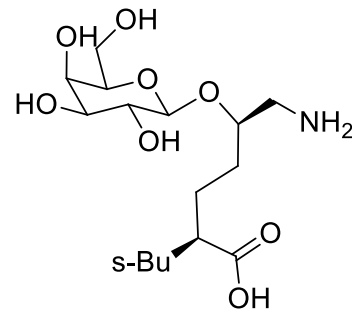

100<smiles>N[C@@H](CO)c1nc(C(=O)O)co1</smiles>

102<smiles>N[C@@H](CC1CCCCC1)C(=O)O</smiles>

119<smiles>[R]c1ccc(C[C@H](N)C(=O)O)cc1</smiles>

$\mathrm{R}=\mathrm{Cl}, \mathrm{Br}, \mathrm{I}, \mathrm{NO}_{2}$ 123<smiles>N[C@@H](Cc1cccs1)C(=O)O</smiles>

120<smiles>N[C@@H](COCc1ccccc1)C(=O)O</smiles>

124<smiles>NC(C(=O)O)C(c1ccccc1)c1ccccc1</smiles>

121<smiles>O=C(O)C1Cc2ccccc2CN1</smiles>

125

Figure 6. Unnatural amino acids utilized in APLs for the treatment of Rheumatoid Arthritis.

Based on their investigations, they determined that Phe265 (p1) is the dominant HLA anchoring residue and that Ala268, Ser269, Glu271 and Thr272 (p4, p5, p7 and p8) are the core TCR contact residues. They then substituted $\mathrm{p} 1$ with a series of unnatural amino acids to attempt to improve affinity (118-125; Figure 6). They chose to modify the HLA contact residues because modifications of TCR contact residues could result in undesired immune response as was the case in clinical trials where patients developed allergic reactions to other APL formulations. This is a challenge for autoimmune peptide therapies: APLs can often induce dangerous allergic or adverse reactions in some individuals, leading to the termination of several clinical trials. ${ }^{54}$ Modification of the anchor residues can also result in a change in the structure or positioning of the protein, and this too can lead to altered T-cell responses despite the homology to the parent epitope.

The APLs generated by Boots had similar binding affinities for DR4 as the original peptides demonstrating the flexibility of the pocket to accept alternatives to a simple phenyl ring. 
Of the substitutions tested, only two were found to be partial activators of T cells (compounds $\mathbf{1 2 1}$ and 125). Many of the amino acids have relatively simple preparations, but $\mathbf{1 2 1}$ is a challenging target. $^{55}$ Optically active glycinamide (126; Scheme 10) is condensed with substituted benzaldehyde 127 to produce, in the presence of an acid catalyst, a mixture of diastereomers (128). These could be readily separated through fractional crystallization to isolate the desired optically active imidazolidinone 129. Boc protection removes the remaining acidic proton to give precursor 130. Deprotonation creates the enol that is then treated with benzhydryl chloride (131) installs the required functionality in 132. A series of deprotections: Boc and imidazolidinone hydrolysis, cleavage of the primary amide, and reduction of the remaining methyl benzyl group, provides the final amino acid 125. ${ }^{55}$
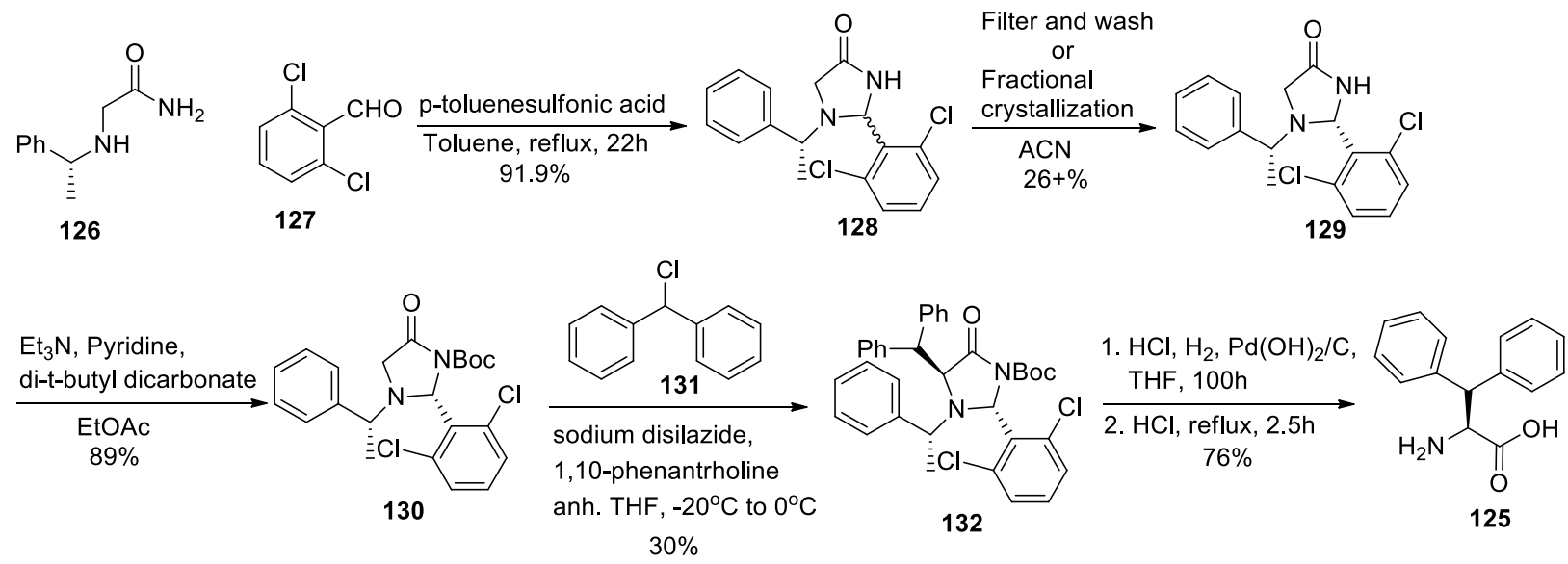

Scheme 10. Synthesis of diphenyl substituted amino acid $\mathbf{1 2 5} .^{55}$

However, incorporating this diphenyl substituted amino acid $\mathbf{1 2 1}$ reduced IFN-y production while 125 increased cytokine production. The exact mechanism for decreased cytokine production is uncertain. While an interesting approach, this strategy did not result in antagonism or prevention of disease progression.

Finally, although not a synthetic amino acid in the same class as those described above, citrullination plays a key role in RA pathogenesis. It can occur because of enzymatic transformation of arginine 133 to citrulline 134 by peptidyl arginine deiminases (PAD) (Scheme 11). It was observed that autoantibodies in the sera of RA patients are capable of recognizing citrullinated peptides which are present in the synovium. ${ }^{56}$ Citrullinated peptides however were not used as a potential therapy but rather as a diagnostic tool. Cyclization of these peptides (which are recognized by autoantibodies) increased affinity to the antibodies, and thus were used to detect their presence in the sera of RA patients more efficiently. ${ }^{57}$ It was also noted that the collagen II epitopes can undergo other modifications as well, such as glycosylation, which are also recognized by $\mathrm{T}$ cells indicating a more complex mechanism. ${ }^{58}$ Citrulline introduction may prove a good starting point for designing the next generation of unnatural amino acids for the treatment of RA. 


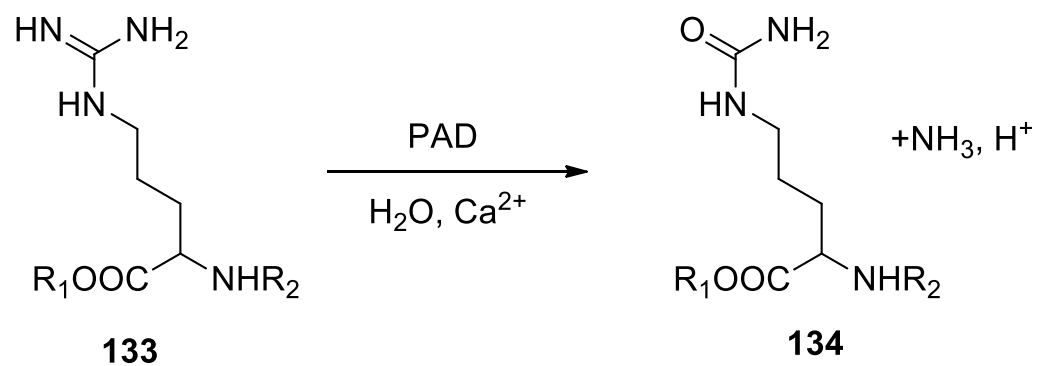

Scheme 11. Conversion of peptidyl-arginine to citrulline by the PAD enzyme.

\section{Multiple Sclerosis}

Multiple sclerosis is an inflammatory disorder of the central nervous system in which demyelination of axons occurs along with plaque formation..$^{59}$ This causes a range of neurological symptoms such as pain, ataxia, motor deficit, visual impairment. ${ }^{60}$

MS has a very strong genetic association with HLA class II genes DR15 and DQw6, which increase susceptibility of individuals. ${ }^{61}$ Myelin basic protein (MBP), proteolipid protein and myelin oligodendrocyte glycoprotein are all suspected MS autoantigens; however, MBP appears the most responsible, and is recognized by the majority of MS patient-derived T-cell lines. The most antigenic sequence appears to be $\mathrm{MPB}_{84-103}$ which contains the immunodominant epitope MPB $83-99 .{ }^{62}$ Crystallization of the HLA-MBP-TCR ternary complex (Figure 7; PDB: 1YMM) reveals key structural aspects of the interactions. The TCR sits off-center over the p2 and $\mathrm{p} 3$ positions which contain His and Phe residues respectively. ${ }^{63}$ These form the major contact points with the TCR $\alpha$ and TCR $\beta$ chains. Lys in P5 makes smaller contributions to TCR binding. Modifications of the $\mathrm{p} 2$ and $\mathrm{p} 3$ residues greatly impacted binding and modification of $\mathrm{p} 5$ affected binding to a lesser degree. ${ }^{64}$ Additionally $\mathrm{p} 4$ appears important for determining T-cell activation as the T-cell receptor interacts directly with the peptide backbone making this position relatively insensitive to substitution if T-cell activation is to be maintained.

Another crystal structure of the HLA obtained by Smith and coworkers, complexed with $\mathrm{MBP}_{83-97}$, showed that Val87 and Phe90 (p1 and p4) were the major HLA anchor residues, with Asn92, Ile93 and Thr95 (p6, p7 and p9 respectively) also playing a supporting role (Crystal structures (1FV1); Figure 7). ${ }^{65}$ In this structure, the side chains of His88, Phe89 and Lys91 in p2, p3 and p5 were oriented away from the pocket which is consistent with the understanding that they act as TCR contact residues. ${ }^{65 a}$ These sites can be modified to alter the binding of APLs with either the HLA or the TCR. ${ }^{66}$ It was noted however that mutations in the peptide sequence of MBP $87-99$ in which Lys91 is mutated to either Arg or Ala and Pro96 is mutated to Ala (generating [Arg91, Ala96] and [Ala91, Ala96] peptides) resulted in antagonistic peptides even though Lys91 has minimal contributions to binding, and Pro96 is not a TCR contact residue. ${ }^{67}$ These modifications can clearly have an impact on the behavior of the adjacent residues. A study by Mantzourani and coworkers showed that these modifications resulted in a change in peptide conformation: the essential TCR anchors at $\mathrm{p} 2$ and $\mathrm{p} 3$ becoming buried into the peptide groove. ${ }^{68}$ This acts as an additional reminder about the complexity of these systems, and emphasizes again the necessity to consider the emergent conformational changes that arise from any substitution. 

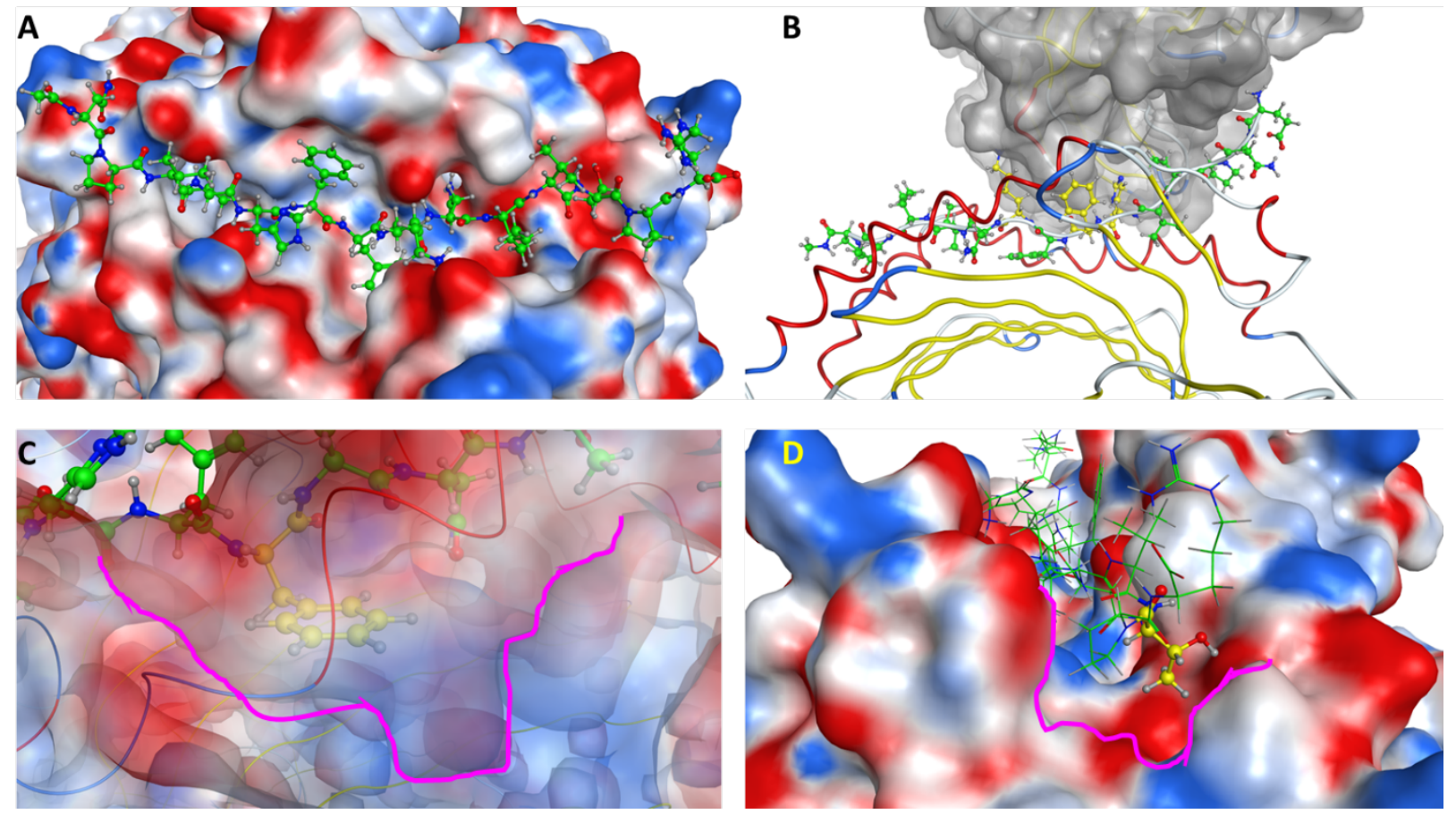

Figure 7. Crystal structures (1FV1) ${ }^{69}$ and the electrostatic surface map of the HLA-DR15 binding pocket with the antigen $\mathrm{MBP}_{83-97}$ highlighted in green. A) Overall view of the peptide-HLA interaction. B) View of the T-cell receptor-antigen-HLA ternary complex. The key TCRinteracting residues, His88, Phe 89 and Lys91 are highlighted in yellow. The surface of the TCR is provided as a translucent grey model, and the HLA is represented by the ribbons. The surface has been removed for clarity. C) Expanded view of the very large p4 pocket partially occupied by a phenylalanine. D) Edge-on view of the peptide showing the interaction between the threonine and the $\mathrm{P} 9$ pocket and end of the binding groove. MBP bends away from the groove and into the solvent at this C-terminus.

In a study conducted by Trager and coworkers, APL peptides were modified with azapeptide linkages in which a carbon in the backbone is replaced by a nitrogen in an attempt to increase protease resistance..$^{70}$ The APL they chose to modify had undergone clinical trials and patients developed an allergic reaction to the peptide. ${ }^{71}$ It was hypothesized that this was caused by use of large doses which were required due to the low bioavailability and stability of the peptide. ${ }^{71}$ This peptide sequence contains TCR contacts in $\mathrm{p} 3$ (Gln) and p6 (Pro) and HLA contacts in $\mathrm{p} 4$ (Ser) p6(Lys) and p9 (Ser), with aza-glycine being introduced at or near TCR contact points. Incorporation of aza-gly in $\mathrm{p} 3$, along with $\mathrm{p} 4$ substitutions to Tyr to increase HLA binding, resulted in the most effective APL: it demonstrated a longer half-life and acted as a partial agonist. In vivo studies in EAE mice showed this peptide was effective in treatment of the disease.

Cyclization of peptides offers a potential solution to the instability of linear peptides and is of great interest. ${ }^{72}$ Peptide cyclizations of previously tested antagonizers based on the MBP $83-99$ immunodominant epitope were synthesized and tested. In one case, the mutant peptide [Ala91]MBP ${ }_{83-99}$ and several analogues were cyclized in a head to tail fashion. ${ }^{73}$. Ala91 was replaced with several other amino acids, and in some cases double mutants were generated to include mutation of Pro96 to Ala96. In the unmodified peptide, Val87 and Phe90 act as MHC anchor residues while His88, Phe89 and Lys91 are TCR contacts. ${ }^{74}$ The cyclic analogues were 
found to be good inhibitors of EAE in mice and inhibit IFN-y production. Additionally, conjugation with reduced mannan through a linker peptide which resulted in increased $\mathrm{Th}_{2}$ response via production of IL-4. ${ }^{75}$ Mannan incorporation can induce either $\mathrm{Th}_{1}$ or $\mathrm{Th}_{2}$ responses depending on whether it is oxidized or reduced via binding to receptors on antigen presenting cells. In a similar study, various cyclic analogues were tested for immunogenicity using blood mononuclear cells obtained from MS patients. ${ }^{76}$ These analogues were also based on the MPB 87 99 epitope and contained mutations at positions 91 and 96 (Lys91 to Arg and Pro96 to Ala double mutant; or only Pro96 to Ala96, single mutant). Both peptides promoted a $\mathrm{Th}_{2}$ cytokine profile and inhibited $\mathrm{T}$ cell proliferation. Both were also capable of preventing the development of EAE in mice when co-injected with an immunogenic peptide. The cyclic peptides also showed increased stability to proteases compared to non-cyclized peptides. The double mutant cyclo[Ala91, Ala96] MBP $87-99$ was also conjugated to reduced mannan and further reduced the Th1 profile. ${ }^{75}$ Another cyclic peptide of [Phe91] MBP $83-99$ conjugated to mannan also prevented T cell proliferation. ${ }^{77}$

In another study, the cyclic and linear [Ala96]MBP $87-99$ was citrullinated, replacing Arg91 and Arg97 post-synthetically using isolated PAD enzyme (see Scheme 11 above). ${ }^{78}$ Citrullination has been implicated in other MHC type II autoimmune disorders such as RA as described above: citrullinated peptides appear to be generally highly antigenic. ${ }^{79}$ As such peptide modifications are common, and even more so in MS patients where the majority of MPB is citrullinated, understanding the mechanism and effects on disease progression is desirable. The citrullinated peptides induced a Th1 response confirming that this modification is indeed immunogenic, and modification of antagonist peptides leads to inflammatory response. In both peptides, citrullinated residues point towards the TCR indicating that their recognition may be responsible for $\mathrm{T}$ cell activation rather than for improving binding to the HLA. The cyclic and linear citrullinated peptides were also conjugated to reduced mannan using a KLH carrier. ${ }^{80}$ The cyclic-KLH-mannan complex induced a very strong T-cell proliferation response and enhanced cytokine IFN- $\gamma$ and IL4 production. The linear peptide, on the other hand, did not stimulate either T-cell proliferation or IFN- $\gamma$ production. Molecular dynamics simulations of the cyclic peptide revealed that it prefers to sit in the middle of the binding pocket with F90 and N92 of the cyclic peptide occupying anchor positions $\mathrm{p} 4$ and $\mathrm{p} 6$, while $\mathrm{p} 1$ and $\mathrm{p} 9$ remain empty presumably due to strain induced by the macrocycle. In contrast, the citrullinated-linear-mannan peptide showed a similar conformation to the unmodified peptide. Differences in their T-cell activation profile can thus be attributed to the structural differences of the two peptides. Several studies have also focused on the use APLs based on myelin oligodendrocyte glycoprotein, another antigenic peptide implicated in MS disease progression. ${ }^{81}$ In one study, the immunogenic $\mathrm{MOG}_{35-55}$ peptide was cyclized in a head to tail fashion. ${ }^{82}$ This peptide was shown to reduce symptoms and severity of EAE. Computational modeling illustrated that this peptide binds HLA-DR2 with decreased affinity. Cyclization then results in different TCR contact points which the authors believe may result in TCR antagonism. Another study utilized $\mathrm{MOG}_{35-55}$ mutants in which TCR contact residues $\mathrm{Arg}^{41}$ and $\mathrm{Arg}^{46}$ were mutated with Ala to generate single or double mutants. ${ }^{83}$ These were compared to cyclic analogues generated by mutating those Arg residues to Lysine and cyclized to Lys55 (terminal lysine) through a side chain. While both were found to suppress EAE, the linear peptides had a stronger effect and cyclic peptides less so.

Another method utilized of increased stability is incorporation of $\beta$-amino acids, which was applied to prepare altered peptide ligands based on the $\mathrm{MOG}_{35-55}$ peptide.$^{84}$ In this study, residue 44F, a TCR contact residue, was replaced with either $\beta$-A or $\beta$-F. The resulting peptides had increased half-lives, potentially due to the removal of a peptidase recognition site within the 
core region of the peptide. Not, only that, but the peptide was found to suppress EAE, even when administered orally. This small change had a profound impact on the function of the immunogenic peptide. Adding the additional atom in the peptide backbone slightly shifts the entire register of the system, and so again has significant distal effects on the interaction between receptor and peptide. $\beta$ amino acids substitutions ${ }^{85}$ may prove to offer a simple solution of introducing unusual spacing and functionality as they can both increase protease resistance and potentially introduce the desired antagonistic properties.

The effects of Thiopalmitoylation on peptide ligands in MS have also been examined. ${ }^{86}$ Thiopalmitoylation is the attachment of palmitic acid to cysteine residues via a thioester bond. ${ }^{87}$ Myelin proteolipid protein (PLP) is abundant in the central nervous system, is often acylated, and has been found to be immunogenic in some MS patients. ${ }^{88}$ Thiopalmitoylation of PLP Th4-117 and PLP $_{139-151}$, the immunogenic epitopes, was shown to increase immunogenicity of the peptides. ${ }^{89}$ The linkage was also found to be important as amide linkage at the $\mathrm{N}$ terminus of the peptides to palmitic acid did not result in immunogenic peptides. ${ }^{89} \mathrm{~A}$ follow-up study to determine the mechanism for increased immunogenicity determined that lipopeptides are absorbed more efficiently in antigen presenting cells. ${ }^{90}$ Cloake and coworkers then modified PLP APLs which were shown to ameliorate EAE disease progression by promoting the uptake and preferential presentation of the modified peptides. ${ }^{91}$ These studies show that the consideration of post translational modifications of the peptides is important. Finally, in addition to modifying contact residues, modifications which affect uptake and promotion should also be considered.

MS is potentially the most promising target of APL and HLAB intervention, and consequently it is a surprise that so little research has been conducted into the use of unnatural amino acids in this disease compared with RA and CD. The solutions from those two diseases should transfer well to this system.

\section{Final thoughts}

One final example, while not strictly for an autoimmune disease, deserves mention in this work. All of the examples described above involve some form of design, whether it be chemical intuition, or some level of computer-assisted design. However, in example after example, the unintended emergent effects induced on surrounding residues has often had a larger impact on binding efficiency or T-cell blocking or modulation than the changed residue. Without a doubt, designed peptides will provide the greatest potential for success in delivering clinically useful APLs or HLABs, but the design problems are significant. The peptides are large, and the receptors are enormous. Solvation and entropic factors must be considered, and these are computationally very intensive and so limit throughput. In a very interesting study Ovaa, Rodenko and co-workers investigated the binding affinity of a consensus antigen for HLA-A2, ${ }^{92}$ a receptor that could be exploited for the development of new anti-viral vaccine formulations. Instead of the careful deliberation, a massively parallel library of epitopes incorporating unnatural amino acids at random positions, of which those provided as Figure 8 are simply a few examples, was prepared. Surprisingly, a large number of the generated epitopes showed considerably higher affinity for the receptor than the consensus sequence. In some cases, this improvement in affinity was by two orders of magnitude. These are generally far simpler residues than those described above. Small alkylated systems $(\mathbf{6 0 , 6 2 , 1 3 5 - 1 4 0})$, or residues with the incorporation of simple $\pi$-systems

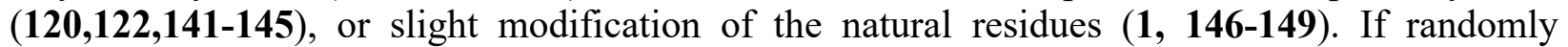
substituting these residues into a peptide can lead to a two-order of magnitude improvement in 
binding affinity, rational design of unnatural amino acids could very well lead to the many orders of magnitude improvement in binding required for the development of clinically-relevant HLABs.

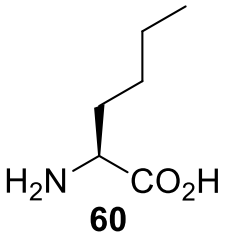

0

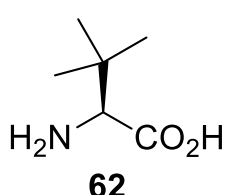

62
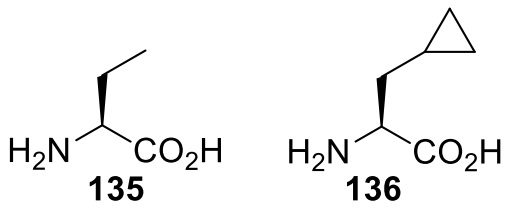<smiles>CCCC(N)C(=O)O</smiles><smiles>CC(C)(C)C[C@H](N)C(=O)O</smiles>

138<smiles>NC(C(=O)O)c1ccccc1</smiles>

143<smiles>O=C(O)[C@H]1C[C@@H](O)CN1</smiles>

1<smiles>CCCCCCC(N)C(=O)O</smiles><smiles>O=C(O)CNCC(=O)O</smiles><smiles>C[C@](N)(C(=O)O)c1ccccc1</smiles>

144<smiles>NC(Cc1ccc(F)cc1)C(=O)O</smiles>

145<smiles>NC(Cc1ccsc1)C(=O)O</smiles>

120<smiles>C=CCC(N)C(=O)O</smiles>

141<smiles>CCC(N)C(=O)O</smiles>

147<smiles>CCSCC(N)C(=O)O</smiles>

148<smiles>NC(Cc1cccnc1)C(=O)O</smiles>

122<smiles>C#CCC(N)C(=O)O</smiles>

142

Figure 8. Most effective unnatural amino acids used by Hoppes and co-workers in their investigation into random substitution of residues into HLA-binding epitopes.

\section{Conclusion}

HLA-specific therapy promises specific targeted treatment options for these and other autoimmune disorders using APLs and HLABs. These ligands bind to the HLA receptor and through either differential $\mathrm{T}$ cell recognition/activation or blocking are able to reduce or even in some cases inhibit these diseases; however, there are three major requirements for these drugs: efficient HLA binding, T-cell blocking or response modulation and protease resistance. Unfortunately, restricting options to the canonical 20 amino acids has failed to properly balance these three requirements. Although the incorporation of unnatural amino acids and using other peptide modification strategies, including cyclization and dimerization has provided encouraging preliminary results in providing high binding affinity, high protease resistance, and efficient T-cell blocking or modulation, the resulting peptides still lack ideal behavior. The rapid increase in computing power and the increasing understanding of receptor-ligand interactions will allow for improvements in designing predictive in silico techniques to help with residue design. Consequently, the next generation of therapeutic candidates will involve the combination of innovative synthetic chemistry, advanced computational modelling, and creative peptide architecture. Autoimmune HLABs and APLs provide an excellent platform for carrying out fundamental research into peptide science while offering an ideal application for exploiting unnatural amino acids for a biomedical application. 


\section{Acknowledgements}

The authors would like to thank the University of Windsor for funding for this project, and DM would like to thank MITACS and the Upper Thames River Conservation Authority for funding. This work was made possible by the facilities of the Shared Hierarchical Academic Research Computing Network (SHARCNET: www.sharcnet.ca) and Compute/Calcul Canada.

1. $\quad$ Newman, D. J.; Cragg, G. M., J. Nat. Prod. 2012, 75 (3), 311-335.

2. $\quad$ Fosgerau, K.; Hoffmann, T., Drug Discovery Today 2015, 20 (1), 122-128.

3. Vlieghe, P.; Lisowski, V.; Martinez, J.; Khrestchatisky, M., Drug Discovery Today 2010, 15 (1), 40-56.

4. (a) Dhanda, S. K.; Usmani, S. S.; Agrawal, P.; Nagpal, G.; Gautam, A.; Raghava, G. P. S., Briefings Bioinf. 2017, 18 (3), 467-478; (b) Maupetit, J.; Derreumaux, P.; Tufféry, P., J. Comput. Chem. 2010, 31 (4), 726-738; (c) Gautam, A.; Chaudhary, K.; Kumar, R.; Sharma, A.; Kapoor, P.; Tyagi, A.; Open source drug discovery, c.; Raghava, G. P. S., J. Transl. Med. 2013, 11, 74-74; (d) Vanhee, P.; van der Sloot, A. M.; Verschueren, E.; Serrano, L.; Rousseau, F.; Schymkowitz, J., Trends Biotechnol. 2011, 29 (5), 231-239.

5. $\quad$ deGruyter, J. N.; Malins, L. R.; Baran, P. S., Biochemistry 2017, 56 (30), 3863-3873.

6. (a) Gentilucci, L.; Marco, R. D.; Cerisoli, L., Curr. Pharm. Des. 2010, 16 (28), 3185-3203;

(b) Russo, A.; Aiello, C.; Grieco, P.; Marasco, D., Curr. Med. Chem. 2016, 23 (8), 748-762; (c) Oueis, E.; Jaspars, M.; Westwood, N. J.; Naismith, J. H., Angew. Chem., Int. Ed. 2016, 55 (19), 5842-5845; (d) Sato, A. K.; Viswanathan, M.; Kent, R. B.; Wood, C. R., Curr. Opin. Biotechnol. 2006, 17 (6), 638-642; (e) Adessi, C.; Soto, C., Curr. Med. Chem. 2002, 9 (9), 963-978; (f) Menegatti, S.; Bobay, B. G.; Ward, K. L.; Islam, T.; Kish, W. S.; Naik, A. D.; Carbonell, R. G., J. Chromatogr. A 2016, 1445 (Supplement C), 93-104.

7. (a) Ramakers, B. E. I.; van Hest, J. C. M.; Lowik, D. W. P. M., Chem. Soc. Rev. 2014, 43 (8), 2743-2756; (b) Behrendt, R.; White, P.; Offer, J., J. Pept. Sci. 2016, 22 (1), 4-27.

8. (a) Wang, L.; Wang, F.-S.; Gershwin, M. E., J. Intern. Med. 2015, 278 (4), 369-395; (b) Tsai, S.; Santamaria, P., Front. Immunol. 2013, 4 (321).

9. $\quad$ Trowsdale, J., Immunol. Lett. 2011, 137 (1), 1-8.

10. Lionetti, E.; Catassi, C., Diseases 2015, 3, 282-293.

11. Yin, L.; Scott-Browne, J.; Kappler, J. W.; Gapin, L.; Marrack, P., Immunol. Rev. 2012, 250 (1), 49-60.

12. Jones, E. Y.; Fugger, L.; Strominger, J. L.; Siebold, C., Nat. Rev. Immunol. 2006, 6 (4), 271-282.

13. (a) Laydon, D. J.; Bangham, C. R. M.; Asquith, B., Philos. Trans. R. Soc., B 2015, 370 (1675); (b) Nikolich-Žugich, J.; Slifka, M. K.; Messaoudi, I., Nat. Rev. Immunol. 2004, 4, 123.

14. Katsara, M.; Minigo, G.; Plebanski, M.; Apostolopoulos, V., Expert Opin. Biol. Ther. 2008, 8 (12), 1873-1884.

15. Alexander, J.; Sidney, J.; Southwood, S.; Ruppert, J.; Oseroff, C.; Maewal, A.; Snoke, K.; Serra, H. M.; Kubo, R. T.; Sette, A.; Grey, H. M., Immunity 1994, 1 (9), 751-761.

16. (a) Thamilarasan, M.; Hecker, M.; Goertsches, R. H.; Paap, B. K.; Schröder, I.; Koczan, D.; Thiesen, H.-J.; Zettl, U. K., J. Neuroinflammation 2013, 10, 126-126; (b) Teitelbaum, D.; Webb, C.; Bree, M.; Meshorer, A.; Arnon, R.; Sela, M., Clin. Immunol. Immunopathol. 1974, 3 (2), 256-262. 
17. Jüse, U.; Arntzen, M.; Højrup, P.; Fleckenstein, B.; Sollid, L. M., Bioorg. Med. Chem. 2011, 19 (7), 2470-2477.

18. Raychaudhuri, S.; Sandor, C.; Stahl, E. A.; Freudenberg, J.; Lee, H.-S.; Jia, X.; Alfredsson, L.; Padyukov, L.; Klareskog, L.; Worthington, J.; Siminovitch, K. A.; Bae, S.-C.; Plenge, R. M.; Gregersen, P. K.; de Bakker, P. I. W., Nat. Genet. 2012, 44 (3), 291-296.

19. Hahn, M.; Nicholson, M. J.; Pyrdol, J.; Wucherpfennig, K. W., Nat. Immunol. 2005, 6, 490.

20. (a) Jüse, U.; van de Wal, Y.; Koning, F.; Sollid, L. M.; Fleckenstein, B., Hum. Immunol. 2010, 71 (5), 475-481; (b) Larché, M.; Wraith, D. C., Nat. Med. 2005, 11, S69.

21. Fasano, A.; Berti, I.; Gerarduzzi, T.; et al., Arch. Intern. Med. 2003, 163 (3), 286-292.

22. Fasano, A.; Catassi, C., Gastroenterology 2001, 120 (3), 636-651.

23. Kim, C.-Y.; Quarsten, H.; Bergseng, E.; Khosla, C.; Sollid, L. M., Proc. Natl. Acad. Sci. U.S.A. 2004, 101 (12), 4175-4179.

24. Fleckenstein, B.; Molberg, O.; Qiao, S.-W.; Schmid, D. G.; von der Mulbe, F.; Elgstoen, K.; Jung, G.; Sollid, L. M., J. Biol. Chem. 2002, 277 (37), 34109-34116.

25. Hovhannisyan, Z.; Weiss, A.; Martin, A.; Wiesner, M.; Tollefsen, S.; Yoshida, K.; Ciszewski, C.; Curran, S. A.; Murray, J. A.; David, C. S.; Sollid, L. M.; Koning, F.; Teyton, L.; Jabri, B., Nature 2008, 456 (7221), 534-8.

26. Schuppan, D., Gastroenterology 2000, 119 (1), 234-242.

27. Henderson, K. N.; Tye-Din, J. A.; Reid, H. H.; Chen, Z.; Borg, N. A.; Beissbarth, T.; Tatham, A.; Mannering, S. I.; Purcell, A. W.; Dudek, N. L.; van Heel, D. A.; McCluskey, J.; Rossjohn, J.; Anderson, R. P., Immunity 2007, 27 (1), 23-34.

28. (a) Shan, L.; Molberg, O.; Parrot, I.; Hausch, F.; Filiz, F.; Gray, G. M.; Sollid, L. M.; Khosla, C., Science (Washington, DC, U. S.) 2002, 297 (5590), 2275-2279; (b) Bergseng, E.; Sidney, J.; Sette, A.; Sollid, L. M., Hum. Immunol. 2008, 69 (2), 94-100.

29. Fraccalvieri, D.; Motta, S.; Galliani, G.; Cavaletti, L.; Bonati, L., Mol. BioSyst. 2014, 10 (8), 2064-2073.

30. Kapoerchan, V. V.; Wiesner, M.; Overhand, M.; van der Marel, G. A.; Koning, F.; Overkleeft, H. S., Bioorg. Med. Chem. 2008, 16 (4), 2053-2062.

31. Gómez-Vidal, J. A.; Silverman, R. B., Org. Lett. 2001, 3 (16), 2481-2484.

32. Kapoerchan, V. V.; Wiesner, M.; Hillaert, U.; Drijfhout, J. W.; Overhand, M.; Alard, P.; van der Marel, G. A.; Overkleeft, H. S.; Koning, F., Molecular Immunology 2010, 47 (5), 10911097.

33. Otsuka, M.; Kittaka, A.; Iimori, T.; Yamashita, H.; Kobayashi, S.; Ohno, M., Chem. Pharm. Bull. 1985, 33, 509-14.

34. Siegel, M.; Xia, J.; Khosla, C., Bioorg. Med. Chem. 2007, 15 (18), 6253-6261.

35. Xia, J.; Siegel, M.; Bergseng, E.; Sollid, L. M.; Khosla, C., J. Am. Chem. Soc. 2006, 128 (6), 1859-1867.

36. Xia, J.; Bergseng, E.; Fleckenstein, B.; Siegel, M.; Kim, C.-Y.; Khosla, C.; Sollid, L. M., Bioorg. Med. Chem. 2007, 15 (20), 6565-6573.

37. Aletaha, D.; Neogi, T.; Silman, A. J.; Funovits, J.; Felson, D. T.; Bingham, C. O.; Birnbaum, N. S.; Burmester, G. R.; Bykerk, V. P.; Cohen, M. D.; Combe, B.; Costenbader, K. H.; Dougados, M.; Emery, P.; Ferraccioli, G.; Hazes, J. M. W.; Hobbs, K.; Huizinga, T. W. J.; Kavanaugh, A.; Kay, J.; Kvien, T. K.; Laing, T.; Mease, P.; Ménard, H. A.; Moreland, L. W.; Naden, R. L.; Pincus, T.; Smolen, J. S.; Stanislawska-Biernat, E.; Symmons, D.; Tak, P. P.; Upchurch, K. S.; Vencovský, J.; Wolfe, F.; Hawker, G., Arthritis Rheum. 2010, 62 (9), 2569-2581. 
38. Singh, J. A.; Cameron, C.; Noorbaloochi, S.; Cullis, T.; Tucker, M.; Christensen, R.; Ghogomu, E. T.; Coyle, D.; Clifford, T.; Tugwell, P.; Wells, G. A., Lancet 386 (9990), 258-265. 39. (a) Dessen, A.; Lawrence, C. M.; Cupo, S.; Zaller, D. M.; Wiley, D. C., Immunity 1997, 7, 473-81; (b) Ohnishi, Y.; Tsutsumi, A.; Sakamaki, T.; Sumida, T., Int. J. Mol. Med. 2003, 11, 331335; (c) Khare, S. D.; Krco, C. J.; Griffiths, M. M.; Luthra, H. S.; David, C. S., The Journal of Immunology 1995, 155 (7), 3653.

40. (a) Rosloniec, E. F.; Whittington, K. B.; Zaller, D. M.; Kang, A. H., The Journal of Immunology 2002, 168 (1), 253; (b) Andersson, E. C.; Hansen, B. E.; Jacobsen, H.; Madsen, L. S.; Andersen, C. B.; Engberg, J.; Rothbard, J. B.; McDevitt, G. S.; Malmström, V.; Holmdahl, R.; Svejgaard, A.; Fugger, L., Proc. Natl. Acad. Sci. U. S. A. 1998, 95 (13), 7574-7579.

41. (a) Zhou, Q.; Cheng, Y.; Lu, H.; Zhou, W.; Li, Z., Hum. Immunol. 2003, 64, 857-865; (b) Cheng, Y. J.; Zhou, Q.; Li, Z. G., Scand. J. Immunol. 2005, 61 (3), 260-265.

42. Myers, L. K.; Rosloniec, E. F.; Seyer, J. M.; Stuart, J. M.; Kang, A. H., The Journal of Immunology 1993, 150 (10), 4652-8.

43. Falcioni, F.; Ito, K.; Vidovic, D.; Belunis, C.; Campbell, R.; Berthel, S. J.; Bolin, D. R.; Gillespie, P. B.; Huby, N.; Olson, G. L.; Sarabu, R.; Guenot, J.; Madison, V.; Hammer, J.; Sinigaglia, F.; Steinmetz, M.; Nagy, Z. A., Nat. Biotech. 1999, 17 (6), 562-567.

44. Knoop, F.; Landmann, G., Z. Physiol. Chem. 1914, 89, 157-159.

45. Bommarius, A. S.; Schwarm, M.; Stingl, K.; Kottenhahn, M.; Huthmacher, K.; Drauz, K., Tetrahedron: Asymmetry 1995, 6, 2851-8.

46. Bolin, D. R.; Swain, A. L.; Sarabu, R.; Berthel, S. J.; Gillespie, P.; Huby, N. J. S.; Makofske, R.; Orzechowski, L.; Perrotta, A.; Toth, K.; Cooper, J. P.; Jiang, N.; Falcioni, F.; Campbell, R.; Cox, D.; Gaizband, D.; Belunis, C. J.; Vidovic, D.; Ito, K.; Crowther, R.; Kammlott, U.; Zhang, X.; Palermo, R.; Weber, D.; Guenot, J.; Nagy, Z.; Olson, G. L., J. Med. Chem. 2000, 43 (11), 2135-2148.

47. Attwood, M. R.; Hassall, C. H.; Krohn, A.; Lawton, G.; Redshaw, S., Journal of the Chemical Society, Perkin Transactions 1 1986, (0), 1011-1019.

48. Robl, J. A.; Karanewsky, D. S.; Asaad, M. M., Tet. Lett. 1995, 36 (10), 1593-1596.

49. Andersson, I. E.; Batsalova, T.; Dzhambazov, B.; Edvinsson, L.; Holmdahl, R.; Kihlberg, J.; Linusson, A., Org. Biomol. Chem. 2010, 8 (13), 2931-2940.

50. Rosloniec, E. F.; Brandstetter, T.; Leyer, S.; Schwaiger, F.-W.; Nagy, Z. A., J. Autoimmun. 2006, 27 (3), 182-195.

51. Chung, J. Y. L.; Wasicak, J. T.; Arnold, W. A.; May, C. S.; Nadzan, A. M.; Holladay, M. W., J. Org. Chem. 1990, 55 (1), 270-275.

52. Adamczyk, M.; Reddy, R. E.; Rege, S. D., Synth. Commun. 2000, 30 (18), 3281-3290.

53. Boots, A. M. H.; Hubers, H.; Kouwijzer, M.; den Hoed-van Zandbrink, L.; WestrekEsselink, B. M.; van Doorn, C.; Stenger, R.; Bos, E. S.; van Lierop, M.-j. C.; Verheijden, G. F.; Timmers, C. M.; van Staveren, C. J., Arthritis Res. Ther. 2007, 9 (4), No pp. given.

54. Bielekova, B.; Goodwin, B.; Richert, N.; Cortese, I.; Kondo, T.; Afshar, G.; Gran, B.; Eaton, J.; Antel, J.; Frank, J. A.; McFarland, H. F.; Martin, R., Nat. Med. 2000, 6, 1167.

55. Saka, Y.; Fujii, A.; Okuro, K.; Mitsuda, M. Process for preparation of optically active amino acids via novel imidazolidinone derivatives. WO2008012974A1, 2008.

56. Vossenaar, E. R.; Radstake, T. R. D.; van der Heijden, A.; van Mansum, M. A. M.; Dieteren, C.; de Rooij, D. J.; Barrera, P.; Zendman, A. J. W.; van Venrooij, W. J., Ann. Rheum. Dis. 2004, 63 (4), 373. 
57. Schellekens, G. A.; Visser, H.; De Jong, B. A. W.; Van Den Hoogen, F. H. J.; Hazes, J. M. W.; Breedveld, F. C.; Van Venrooij, W. J., Arthritis Rheum. 2000, 43 (1), 155-163.

58. Corthay, A.; Backlund, J.; Holmdahl, R., Ann. Med. 2001, 33 (7), 456-465.

59. Huseby, E. S.; Liggitt, D.; Brabb, T.; Schnabel, B.; Ohlen, C.; Goverman, J., J. Exp. Med. 2001, $194(5), 669-676$.

60. Cottrell, D. A.; Kremenchutzky, M.; Rice, G. P. A.; Koopman, W. J.; Hader, W.; Baskerville, J.; Ebers, G. C., Brain 1999, 122 (4), 625-639.

61. Fogdell, A.; Hillert, J.; Sachs, C.; Olerup, O., Tissue Antigens 1995, 46 (4), 333-336.

62. (a) Valli, A.; Sette, A.; Kappos, L.; Oseroff, C.; Sidney, J.; Miescher, G.; Hochberger, M.; Albert, E. D.; Adorini, L., Journal of Clinical Investigation 1993, 91 (2), 616-28; (b) Krogsgaard, M.; Wucherpfennig, K. W.; Canella, B.; Hansen, B. E.; Svejgaard, A.; Pyrdol, J.; Ditzel, H.; Raine, C.; Engberg, J.; Fugger, L., J. Exp. Med. 2000, 191 (8), 1395-1412.

63. Hahn, M.; Nicholson, M. J.; Pyrdol, J.; Wucherpfennig, K. W., Nat. Immunol. 2005, 6 (5), 490-496.

64. Hausmann, S.; Martin, M.; Gauthier, L.; Wucherpfennig, K. W., The Journal of Immunology 1999, 162 (1), 338.

65. (a) Smith, K. J.; Pyrdol, J.; Gauthier, L.; Wiley, D. C.; Wucherpfennig, K. W., J. Exp. Med. 1998, 188 (8), 1511-1520; (b) Mantzourani, E. D.; Platts, J. A.; Brancale, A.; Mavromoustakos, T. M.; Tselios, T. V., J. Mol. Graphics Modell. 2007, 26 (2), 471-481.

66. de Haan, E. C.; Moret, E. E.; Wagenaar-Hilbers, J. P. A.; Liskamp, R. M. J.; Wauben, M. H. M., Molecular Immunology 2005, 42 (3), 365-373.

67. Mantzourani, E. D.; Platts, J. A.; Brancale, A.; Mavromoustakos, T. M.; Tselios, T. V., J. Mol. Graphics Modell. 2007, 26 (2), 471-481.

68. Mantzourani, E. D.; Blokar, K.; Tselios, T. V.; Matsoukas, J. M.; Platts, J. A.; Mavromoustakos, T. M.; Grdadolnik, S. G., Bioorg. Med. Chem. 2008, 16 (5), 2171-2182.

69. Li, Y.; Li, H.; Martin, R.; Mariuzza, R. A., J. Mol. Biol. 2000, 304 (2), 177-188.

70. Trager, N. N. M.; Butler, J. T.; Harmon, J.; Mount, J.; Podbielska, M.; Haque, A.; Banik, N. L.; Beeson, C. C., Mol. Neurobiol. 2017, Ahead of Print.

71. Kappos, L.; Comi, G.; Panitch, H.; Oger, J.; Antel, J.; Conlon, P.; Steinman, L.; Rae-Grant, A.; Castaldo, J.; Eckert, N.; Guarnaccia, J. B.; Mills, P.; Johnson, G.; Calabresi, P. A.; Pozzilli, C.; Bastianello, S.; Giugni, E.; Witjas, T.; Cozzone, P.; Pelletier, J.; Pohlau, D.; Przuntek, H.; Hoffmann, V.; Bever, C.; Katz, E.; Clanet, M.; Berry, I.; Brassat, D.; Brunet, I.; Edan, G.; Duquette, P.; Radue, E.-W.; Schott, D.; Lienert, C.; Taksaoui, A.; Rodegher, M.; Filippi, M.; Evans, A.; Bourgouin, P.; Zijdenbos, A.; Salem, S.; Ling, N.; Alleva, D.; Johnson, E.; Gaur, A.; Crowe, P.; Liu, X.-J., Nat. Med. 2000, 6 (10), 1176-1182.

72. (a) Alexopoulos, K.; Panagiotopoulos, D.; Mavromoustakos, T.; Fatseas, P.; ParedesCarbajal, M. C.; Mascher, D.; Mihailescu, S.; Matsoukas, J., J. Med. Chem. 2001, 44, 328-39; (b) Roumelioti, P.; Polevaya, L.; Zoumpoulakis, P.; Giatas, N.; Mutule, I.; Keivish, T.; Zoga, A.; Vlahakos, D.; Iliodromitis, E.; Kremastinos, D.; Grdadolnik, S. G.; Mavromoustakos, T.; Matsoukas, J., Bioorg. Med. Chem. Lett. 2002, 12 (18), 2627-2633.

73. Katsara, M.; Deraos, G.; Tselios, T.; Matsoukas, J.; Apostolopoulos, V., J. Med. Chem. 2008, 51 (13), 3971-3978.

74. Katsara, M.; Yuriev, E.; Ramsland, P. A.; Tselios, T.; Deraos, G.; Lourbopoulos, A.; Grigoriadis, N.; Matsoukas, J.; Apostolopoulos, V., Immunology 2009, 128 (4), 521-533.

75. Katsara, M.; Deraos, G.; Tselios, T.; Matsoukas, M.-T.; Friligou, I.; Matsoukas, J.; Apostolopoulos, V., J. Med. Chem. 2009, 52 (1), 214-218. 
76. Matsoukas, J.; Apostolopoulos, V.; Kalbacher, H.; Papini, A.-M.; Tselios, T.; Chatzantoni, K.; Biagioli, T.; Lolli, F.; Deraos, S.; Papathanassopoulos, P.; Troganis, A.; Mantzourani, E.; Mavromoustakos, T.; Mouzaki, A., J. Med. Chem. 2005, 48, 1470-1480.

77. Day, S.; Tselios, T.; Androutsou, M.-E.; Tapeinou, A.; Frilligou, I.; Stojanovska, L.; Matsoukas, J.; Apostolopoulos, V., Front. Immunol. 2015, 6 (136).

78. Deraos, G.; Chatzantoni, K.; Matsoukas, M.-T.; Tselios, T.; Deraos, S.; Katsara, M.; Papathanasopoulos, P.; Vynios, D.; Apostolopoulos, V.; Mouzaki, A.; Matsoukas, J., J. Med. Chem. 2008, 51 (24), 7834-7842.

79. Tranquill, L. R.; Cao, L.; Ling, N. C.; Kalbacher, H.; Martin, R. M.; Whitaker, J. N., Mult. Scler. 2000, 6, 220-225.

80. Apostolopoulos, V.; Deraos, G.; Matsoukas, M.-T.; Day, S.; Stojanovska, L.; Tselios, T.; Androutsou, M.-E.; Matsoukas, J., Bioorg. Med. Chem. 2017, 25, 528-538.

81. Wallstrom, E.; Khademi, M.; Andersson, M.; Weissert, R.; Linington, C.; Olsson, T., Eur. J. Immunol. 1998, 28, 3329-35.

82. Lourbopoulos, A.; Deraos, G.; Matsoukas, M.-T.; Touloumi, O.; Giannakopoulou, A.; Kalbacher, H.; Grigoriadis, N.; Apostolopoulos, V.; Matsoukas, J., Bioorg. Med. Chem. 2017, 25, 4163-4174.

83. Tselios, T.; Aggelidakis, M.; Tapeinou, A.; Tseveleki, V.; Kanistras, I.; Gatos, D.; Matsoukas, J., Molecules 2014, 19 (11), 17968-17984.

84. McDonald, C. A.; Payne, N. L.; Sun, G.; Clayton, D. J.; Del Borgo, M. P.; Aguilar, M.-I.; Perlmutter, P.; Bernard, C. C. A., J. Neuroimmunol. 2014, 277 (1-2), 67-76.

85. Cabrele, C.; Martinek, T. A.; Reiser, O.; Berlicki, Ł., J. Med. Chem. 2014, 57 (23), 97189739.

86. Beaino, W.; Trifilieff, E., Bioconjugate Chem. 2010, 21 (8), 1439-1447.

87. Denis, B.; Trifilieff, E., J. Pept. Sci. 2000, 6 (8), 372-377.

88. (a) Messier, A. M.; Bizzozero, O. A., Neurochem. Res. 2000, 25 (4), 449-455; (b) Trotter, J. L.; Hickey, W. F.; van, d. V. R. C.; Sulze, L., J Neuroimmunol 1991, 33 (1), 55-62.

89. Greer, J. M.; Denis, B.; Sobel, R. A.; Trifilieff, E., The Journal of Immunology 2001, 166 (11), 6907-6913.

90. Pfender, N. A.; Grosch, S.; Roussel, G.; Koch, M.; Trifilieff, E.; Greer, J. M., The Journal of Immunology 2008, 180 (3), 1398-404.

91. Cloake, N. C.; Beaino, W.; Trifilieff, E.; Greer, J. M., The Journal of Immunology 2014, $192(5), 2244-2251$.

92. Hoppes, R.; Oostvogels, R.; Luimstra, J. J.; Wals, K.; Toebes, M.; Bies, L.; Ekkebus, R.;

Rijal, P.; Celie, P. H. N.; Huang, J. H.; Emmelot, M. E.; Spaapen, R. M.; Lokhorst, H.; Schumacher, T. N. M.; Mutis, T.; Rodenko, B.; Ovaa, H., The Journal of Immunology 2014, 193 (10), 4803-4813. 